\title{
Evaluation of a photosynthesis-based biogenic isoprene emission scheme in JULES and simulation of isoprene emissions under present-day climate conditions
}

\author{
F. Pacifico ${ }^{1,2, *}$, S. P. Harrison ${ }^{2,3}$, C. D. Jones ${ }^{1}$, A. Arneth ${ }^{4,5}$, S. Sitch ${ }^{6}$, G. P. Weedon ${ }^{1}$, M. P. Barkley ${ }^{7, * *}$, P. I. Palmer ${ }^{7}$, \\ D. Serça ${ }^{8}$, M. Potosnak ${ }^{9}$, T.-M. Fu ${ }^{10}$, A. Goldstein ${ }^{11}$, J. Bai ${ }^{12}$, and G. Schurgers ${ }^{4}$ \\ ${ }^{1}$ Met Office Hadley Centre, Exeter, EX1 3PB, UK \\ ${ }^{2}$ School of Geographical Sciences, University of Bristol, Bristol, BS8 1SS,UK \\ ${ }^{3}$ School of Biological Sciences, Macquarie University, North Ryde, NSW 2109, Australia \\ ${ }^{4}$ Department of Earth and Ecosystem Sciences, University of Lund, Lund, 22362, Sweden \\ ${ }^{5}$ Karlsruhe Institute for Technology, Institute of Meteorology and Climate Research (KIT/IMK-IFU), Kreuzeckbahnstr. 19, \\ 82467 Garmisch-Partenkirchen, Germany \\ ${ }^{6}$ School of Geography, University of Leeds, Leeds, LS2 9JT, UK \\ ${ }^{7}$ School of GeoSciences, University of Edinburgh, Edinburgh, EH9 3JW, UK \\ ${ }^{8}$ Laboratoire d'Aérologie, Université deToulouse, Toulouse, 31400, France \\ ${ }^{9}$ DePaul University, Environmental Science Program, Chicago, IL 60614, USA \\ ${ }^{10}$ Department of Atmospheric and Oceanic Sciences, School of Physics, Peking University, Beijing, China \\ ${ }^{11}$ Dept. of Environmental Science, Policy, and Management, University of California at Berkeley, Berkeley, CA94720, USA \\ ${ }^{12}$ LAGEO, Institute of Atmospheric Physics, Chinese Academy of Sciences, Beijing, 100029, China \\ * now at: College of Engineering, Mathematics and Physical Sciences, University of Exeter, Exeter, EX4 4QF, UK \\ ** now at: EOS Group, Department of Physics and Astronomy, University of Leicester, LE1 7RH, UK
}

Received: 16 September 2010 - Published in Atmos. Chem. Phys. Discuss.: 18 November 2010

Revised: 20 April 2011 - Accepted: 1 May 2011 - Published: 11 May 2011

\begin{abstract}
We have incorporated a semi-mechanistic isoprene emission module into the JULES land-surface scheme, as a first step towards a modelling tool that can be applied for studies of vegetation - atmospheric chemistry interactions, including chemistry-climate feedbacks. Here, we evaluate the coupled model against local above-canopy isoprene emission flux measurements from six flux tower sites as well as satellite-derived estimates of isoprene emission over tropical South America and east and south Asia. The model simulates diurnal variability well: correlation coefficients are significant (at the $95 \%$ level) for all flux tower sites. The model reproduces day-to-day variability with significant correlations (at the $95 \%$ confidence level) at four of the six flux tower sites. At the UMBS site, a complete set of seasonal observations is available for two years (2000 and 2002). The
\end{abstract}

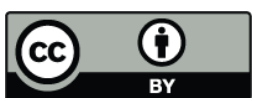

Correspondence to: F. Pacifico (f.m.pacifico@exeter.ac.uk) model reproduces the seasonal pattern of emission during 2002, but does less well in the year 2000. The model overestimates observed emissions at all sites, which is partially because it does not include isoprene loss through the canopy. Comparison with the satellite-derived isoprene-emission estimates suggests that the model simulates the main spatial patterns, seasonal and inter-annual variability over tropical regions. The model yields a global annual isoprene emission of $535 \pm 9 \mathrm{TgC} \mathrm{yr}^{-1}$ during the $1990 \mathrm{~s}, 78 \%$ of which from forested areas.

\section{Introduction}

Isoprene $\left(\mathrm{C}_{5} \mathrm{H}_{8}\right)$ is quantitatively the most important of the non-methane biogenic volatile organic compounds (BVOCs) emitted into the atmosphere (Pacifico et al., 2009). Terrestrial vegetation is the main source (Guenther et al., 2006), although not all plants emit isoprene (Harley et al., 1999;

Published by Copernicus Publications on behalf of the European Geosciences Union. 
Kesselmeier and Staudt, 1999). Tropical broadleaf trees are considered to be the main contributors to global isoprene emissions (Guenther et al., 2006). Isoprene is a carboncontaining compound and - after oxidation in the atmosphere - a carbon dioxide $\left(\mathrm{CO}_{2}\right)$ precursor, so it is a potentially significant term in the global carbon cycle (Guenther, 2002). Isoprene also modulates tropospheric ozone $\left(\mathrm{O}_{3}\right)$ and methane $\left(\mathrm{CH}_{4}\right)$ concentrations (Hofzumahaus et al., 2009) and is a source of secondary organic aerosol (SOA; Claeys et al., 2004), which affects cloud properties and the surface radiation budget.

Vegetation species composition determines overall emission capacity (Niinemets et al., 2010a, b), but the main environmental controls on isoprene emissions are light (e.g., Monson and Fall, 1989), temperature (e.g., Guenther et al., 1993), atmospheric $\mathrm{CO}_{2}$ concentration (e.g., Monson et al., 2007) and drought (e.g., Pegoraro et al., 2004; Monson et al., 2007). In the short-term, isoprene emission increases with light and falls to near zero almost immediately after illumination ceases. Isoprene emission increases with temperature until a temperature optimum of ca. $40^{\circ} \mathrm{C}$ (Niinemets et al., 1999). Moreover, measurements have demonstrated that high concentrations of $\mathrm{CO}_{2}$ inhibit isoprene emission, but with potentially different response patterns to short-and long-term changes in the $\mathrm{CO}_{2}$ burden (see summary of studies in Young et al., 2009 and Pacifico et al., 2009). The limited number of observational and laboratory studies suggest that isoprene emissions are not immediately affected by mild water stress, even when this stress is already affecting photosynthesis (e.g., Sharkey and Loreto, 1993), but the onset of more severe drought causes isoprene emissions to decline substantially (e.g., Pegoraro et al., 2004; Monson et al., 2007). The strong dependence of isoprene emissions on temperature means that isoprene emissions are likely to increase under future climate conditions, although such an increase may be offset by the inhibition of leaf isoprene production emissions that is observed at higher levels of $\mathrm{CO}_{2}$ (Arneth et al., 2007a). Research on quantifying how isoprene emissions will change (and the magnitude of potential feedbacks on atmospheric chemistry and climate) is still in its infancy (see summary of studies in Pacifico et al., 2009).

Biogenic isoprene emissions were originally modelled using empirical relationships between specific environmental controls and emissions, applying a number of algorithms for the short-and long-term influence of changing environmental conditions (Guenther et al., 1991, 1993, 1995, 2006). More recently, photosynthesis-based schemes have been developed to relate isoprene emission to substrate production mechanistically (Niinemets et al., 1999; Martin et al., 2000; Zimmer et al., 2003; Arneth et al., 2007b). Of these semimechanistic models, the Arneth et al. (2007b) scheme is the only one that includes the atmospheric $\mathrm{CO}_{2}$ inhibition of isoprene emission, albeit in an empirical form. The scheme has already been coupled to the Lund Potsdam Jena Dynamic Global Vegetation Model (LPJ-DGVM; Sitch et al., 2003) and to the Lund Potsdam Jena General Ecosystem Simulator (LPJ-GUESS; Smith et al., 2001), and applied at both regional (Arneth et al., 2008b) and global (Arneth et al., 2007a) scales. In this paper, we describe the validation of a modified version of the Arneth et al. (2007b) scheme that has been implemented in the Joint UK Land Environmental Simulator (JULES; Best et al., 2011; Clark et al., 2011; www.jchmr.org/jules). A version of JULES including isoprene will be the land-surface component of the new Hadley Centre Global Environmental Model (HadGEM3). Inclusion of process-based isoprene emissions is necessary in order to quantify the feedbacks between biogenic emissions, atmospheric chemistry and climate within a global Earth System model under current and future climates (e.g., Arneth et al., 2010). The work described here provides a comprehensive evaluation of the performance of the land surface model in simulating isoprene emissions, a necessary step to enhance confidence in feedback estimates.

\section{Methods}

We have incorporated the isoprene emission scheme described in Arneth et al. (2007b) into the frame work of the JULES land-surface model. Here, we first describe the most important features of JULES, we then outline the original isoprene emission scheme, before describing the necessary modifications made to couple the two components. We go onto describe our strategy for the evaluation of the coupled scheme under present-day climate conditions (various time periods from 1995 to 2004). Finally, we describe the protocol for a global simulation of isoprene emissions under presentday conditions (1990 to 1999).

\subsection{The JULES land-surface scheme}

JULES is a UK community land-surface model, based on the MOSES2 (Met Office Surface Exchange Scheme version 2; Essery et al., 2003) land surface scheme used in the UK Met Office Hadley Centre climate model HadGEM (Johns et al., 2006). JULES is intended to replace MOSES in HadGEM3. JULES can be run at a single point or in gridded mode for any number of grid boxes, with a typical time step of 30 to $60 \mathrm{~min}$. The meteorological data used to run JULES are: downward longwave radiation, downward shortwave radiation, precipitation, air pressure, specific humidity, air temperature, and wind speed. These data need to have sub-daily resolution and can be interpolated by JULES itself to the appropriate model time step if necessary. JULES has five plantfunctional types (PFTs), namely broadleaf trees, needleleaf trees, $\mathrm{C}_{3}$ grass, $\mathrm{C}_{4}$ grass, and shrubs, and uses a further four surface types (urban, inland water, bare soil and ice). Each grid box can consist of a number of vegetation and surface types. In agricultural areas grasses are assumed to represent crops, without any change in their parameterization 
(following e.g. Arneth et al., 2008b). JULES can simulate vegetation dynamics using the TRIFFID DGVM (Cox et al., 2000; Cox, 2001) or the fractional cover of each vegetation type can be prescribed, as in this study.

The photosynthesis modules for $\mathrm{C}_{3}$ and $\mathrm{C}_{4}$ plants are based on the work of Collatz et al. (1991) and Collatz et al. (1992), respectively. A comprehensive description of the JULES photosynthesis scheme is given in Cox et al. (1998). The rate of gross photosynthesis is calculated as the minimum of three limiting factors: the Rubisco limited rate of gross photosynthesis, the light-limited rate of gross photosynthesis, and the limitation associated with transport of photosynthetic products for $\mathrm{C}_{3}$ plants and PEPcarboxylase limitation for $\mathrm{C}_{4}$ grasses. Photosynthetically active radiation (PAR) and leaf nitrogen are assumed to decrease exponentially through the canopy (Sellers et al., 1992; Mercado et al., 2007). Canopy photosynthesis is calculated as the sum over all canopy layers (10 layers were used in this study). Leaf phenology is updated on a daily basis, using accumulated temperature-dependent leaf turnover rates. The ability of JULES to simulate photosynthesis has been tested in recent model benchmarking studies, including at ten eddy correlation sites covering the major biomes of the globe (Blyth et al., 2010, 2011) and at regional and global scales, using atmospheric $\mathrm{CO}_{2}$ measurements (Cadule et al., 2010; Blyth et al., 2010, 2011). Blyth et al. (2010, 2011) demonstrates the satisfactory performance of JULES in simulating concurrently the terrestrial carbon and water cycles.

\subsection{Isoprene emission scheme}

The Arneth et al. (2007b) isoprene emission scheme is based on the biochemical model for isoprene emission developed by Niinemets et al. (1999). In the Niinemets et al. (1999) model, isoprene emission depends on the electron requirement for isoprene synthesis. The model assumes that all isoprene emitted from plant leaves is synthesized in the chloroplasts via the 1-deoxy-xylulose-5-phosphate (DXP) pathway and that a certain proportion of electrons released by PSII (Photosystem II) is used in isoprene synthesis. This proportion is calculated from the estimated energy and redoxequivalents requirements to reduce isoprene from the initial steps of carbon assimilation, considering the requirements of 6 moles assimilated $\mathrm{CO}_{2}$ for one mole of isoprene produced. The assumption that co-enzymes, rather than carbon precursors, are the rate-limiting step has been shown to reproduce the correct response of isoprene emission to light and temperature under present-day conditions (Niinemets et al., 1999; Arneth et al., 2007b). However, the effects of changing $\mathrm{CO}_{2}$ concentration, which has been hypothetically linked to competition for carbon substrate (Rosenstiel et al., 2004), need to be included empirically (Arneth et al., 2007b).

When the rate of regeneration of ribulose 1,5-bisphosphate (RuBP) through electron transport is limiting, photosynthetic electron transport $(J)$ is (Farquhar et al., 1980):

$$
J=\frac{\left(A_{J}+R_{\mathrm{D}}\right)\left(4 C_{I}+8 \Gamma\right)}{C_{I}-\Gamma}
$$

where $A_{J}$ is leaf level net photosynthesis when RuBP is limiting; $R_{\mathrm{D}}$ is leaf level dark respiration; $C_{I}$ is leaf internal $\mathrm{CO}_{2}$ concentration and $\Gamma$ is photorespiration compensation point.

Based on the co-enzyme and energetic requirements for isoprene synthesis, Niinemets et al. (1999) assume that isoprene emission is nicotinamide adenine dinucleotide phosphate (NADPH) limited. Given that the NADPH requirement per $\mathrm{CO}_{2}$ mole assimilated is 1.17 times higher for isoprene synthesis than for sugar synthesis and that for each isoprene molecule released $6 \mathrm{CO}_{2}$ molecules must be assimilated, the rate of photosynthetic electron transport to sustain isoprene synthesis and emission at the leaf level $\left(I_{1}\right)$ is:

$J_{\text {isoprene }}=\frac{6 I_{1}\left(4.67 C_{I}+9.33 \Gamma\right)}{C_{I}-\Gamma}$

So

$I_{1}=\varepsilon \frac{\left(A_{J}+R_{\mathrm{D}}\right)\left(4 C_{I}+8 \Gamma\right)}{6\left(4.67 C_{I}+9.33 \Gamma\right)}$

where

$\varepsilon=\frac{J_{\text {isoprene }}}{J_{\mathrm{t}}} \approx \frac{J_{\text {isoprene }}}{J}$ as $J_{\mathrm{t}}=J+J_{\mathrm{e}} \approx J$

$J_{\mathrm{t}}$ is the total electron transport rate and $J_{\mathrm{e}}$ is the extra electron transport rate needed to reduce the sugars to isoprene. $J_{\mathrm{e}}$ is relatively small and can be neglected (Niinemets et al., 1999).

To take advantage of published isoprene emission factors (IEFs), i.e. PFT-specific basal isoprene emission at the leaf level under standard conditions (i.e. temperature $T_{\mathrm{st}}$ of $30^{\circ} \mathrm{C}$, photosynthetically active radiation of $1000 \mu \mathrm{mol} \mathrm{m}^{-2} \mathrm{~s}^{-1}$ and $\mathrm{CO}_{2}$ atmospheric concentration of $370 \mathrm{ppm}$, see e.g. Guenther et al., 1995; Arneth et al., 2007b) assigns PFTspecific values to $\varepsilon$ such that $I_{1}$ is equal to IEF. Leaf-level isoprene emission $\left(I_{1}\right)$ is then given by:

$I_{1}=\mathrm{IEF} \frac{A_{J}+R_{\mathrm{D}}}{\left(A_{J}\right)_{\mathrm{st}}+R_{\mathrm{D}_{\mathrm{st}}}} f_{T} \cdot f_{\mathrm{CO}_{2}}$

and:

$f_{T}=\min \left[e^{a_{T}\left(T-T_{\mathrm{st}}\right)} ; 2.3\right]$

$f_{\mathrm{CO}_{2}}=\frac{C_{I_{\mathrm{st}}}}{C_{I}}$

where $T$ is air temperature and the "st" subscript indicates that the variable is measured under standard conditions (see above). The empirical factor $a_{T}$ is set to $0.1 \mathrm{~K}$ and accounts for the higher temperature optimum of isoprene synthesis compared to that of the electron transport rate.

Although isoprene is produced in the chloroplast from precursors formed during photosynthesis, there are differences 
in the short-term response of carbon assimilation and isoprene emission, such as the higher temperature optimum of isoprene synthase (Monson et al., 1992). The empirical temperature dependent factor $f_{T}$ (Arneth et al., 2007b) simulates this effect.

The empirical factor $f_{\mathrm{CO}_{2}}$ (Arneth et al., 2007b) models the inhibition of isoprene emission with increasing atmospheric $\mathrm{CO}_{2}$ concentration. While for the simulation of changes in the long-term $\mathrm{CO}_{2}$ growth environment $C_{I}$ under non-water stressed conditions is applied, in principle, the calculation of $f_{\mathrm{CO}_{2}}$ could also implicitly include the short-term response of isoprene emission to drought stress (Monson et al., 2007). During periods of water limitation, JULES simulates a closure of stomata, thus $C_{I}$ decreases and therefore $f_{\mathrm{CO}_{2}}$ and consequently isoprene emission increases. This could compensate - at least for a period of a few days for the decline in photosynthesis (and hence isoprene precursors).

Isoprene is not stored in the leaf (Sanadze, 2004) and therefore emitted isoprene reflects the instantaneous rate of synthesis.

\subsection{Coupling of the isoprene emission scheme into JULES}

The structure of JULES required a modification of the original Arneth et al. (2007b) scheme because electron transport is not explicitly simulated in the JULES photosynthesis scheme. We assume that the rate of net photosynthesis $(A)$ is a reasonable approximation to the electron transport dependent rate of net photosynthesis. The limiting rate of photosynthesis varies during the day and through the canopy (Sharkey, 1985). Electron transport limits photosynthesis under low light conditions, i.e. overcast/cloudy conditions, at the start and end of the day, for shaded leaves and understory vegetation. Under high light conditions ribulose1,5-bisphosphate (RuBP), and not electron transport, limits photosynthesis, but under those conditions isoprene emission is mainly controlled by temperature. And simulate abovecanopy isoprene emission $(I)$ as:

$I=\mathrm{IEF} \frac{A_{\text {canopy }}+R_{\text {Dcanopy }}}{A_{\mathrm{st}}+R_{\mathrm{D}_{\mathrm{st}}}} f_{T} \cdot f_{\mathrm{CO}_{2}}$

where canopy level net photosynthesis and dark respiration are used to scale up isoprene emissions to the canopy level.

Equation (8) describes the strong relationship between isoprene production and photosynthesis (Delwiche and Sharkey, 1993), but also takes into account the $\mathrm{CO}_{2}$ inhibition $\left(f_{\mathrm{CO}_{2}}\right)$ and the fact that temperature optimum for photosynthesis is lower than for isoprene synthesis $\left(f_{T}\right)$.

\subsection{Evaluation strategy against ground-based isoprene flux measurements}

Ground-based measurements of above-canopy isoprene fluxes, with temporal resolution and length of measurements sufficient for our purpose are only available from 6 sites (see Table 1). These sites are located in broadleaf forests, specifically temperate deciduous broadleaf forest and tropical rain forest (Table 1). Measurements have generally been made for a relatively short period within the growing season when the leaves are mature; only the record from the University of Michigan Biological Station (UMBS; Pressley et al., 2005) covers more than one year. We used the available data from all of the flux tower sites to evaluate diurnal cycle and dayto-day variability in isoprene emission. The UMBS site has been used to evaluate the seasonal cycle during 2000 and 2002, while the Harvard forest site has been used to evaluate the 1995 seasonal cycle. Data acquisition problems delayed the start of measurements at the UMBS site in 2001 until after the onset of isoprene emissions and measurements were not continued until the end of the growing season. We therefore cannot use the data from 2001 to evaluate the seasonal cycle of isoprene emissions.

We simulate isoprene emissions at each flux site using the single-point version of JULES. We used locally measured IEFs at La Verdière and Montmeyan sites (Dominique Serça, unpublished data); when local IEFs were not available, we used standard IEF values for the appropriate vegetation type derived from Guenther et al. (1995): $45 \mu \mathrm{gC} \mathrm{gdw}{ }^{-1} \mathrm{~h}^{-1}$ for temperate deciduous broadleaf forest and $24 \mu \mathrm{gC} \mathrm{gdw}^{-1} \mathrm{~h}^{-1}$ for tropical rain forest. LAI is simulated by JULES. The meteorological data used to run JULES were either measurements made on-site (UMBS, Harvard Forest, Manaus and Santarem km 67) or were derived from nearby meteorological stations (data from Puechabon $43.7^{\circ} \mathrm{N}, 3.6^{\circ} \mathrm{E}$ were used for La Verdière and Montmeyan). Although isoprene fluxes were generally only measured for short periods, meteorological observations were collected for longer (at least two years). However, meteorological data were not available at the hourly time step on which the model was run. It was therefore necessary to fill these observational gaps. Since the gaps were typically several days long interpolation was not feasible. Instead missing observations were replaced by the average values of that time step from other years. For example, if data for 11:00 a.m. on the 24 April was missing in one year, then we used the average value for this time step in previous years.

This method maintains the diurnal-and seasonal-cycle of each variable at the expense of reduced variance. The gap-filling technique was not applied to rainfall or snowfall rates because it would potentially lead to erroneous introduction of small-scale precipitation events (from the averaging across years). We therefore assumed no precipitation/snowfall when data are missing. The percentage of time steps with missing data is less than $1.5 \%$ for rainfall. The number of missing snowfall data points is larger at most of the sites (more than $82 \%$; the exception is Harvard, where there are no snowfall missing data). However, snowfall is only likely to occur during times when the trees are leafless, thus the absence of this information will have no impact on 
Table 1. Description of ground-based isoprene flux tower sites.

\begin{tabular}{|c|c|c|c|c|c|c|c|c|}
\hline $\begin{array}{l}\text { Site and } \\
\text { Location }\end{array}$ & Record Period & Biome & $\begin{array}{l}\text { JULES } \\
\text { PFT }\end{array}$ & $\begin{array}{l}\text { Dominant } \\
\text { Species }\end{array}$ & $\begin{array}{l}\text { Local IEF } \\
\left(\mu \mathrm{gC} \mathrm{gdw}{ }^{-1}\right. \\
\left.\mathrm{h}^{-1}\right)\end{array}$ & $\begin{array}{l}\text { IEF from } \\
\text { Guenther et al. } \\
(1995) \\
\left(\mu \mathrm{gC} \mathrm{gdw}^{-1} \mathrm{~h}^{-1}\right)\end{array}$ & $\begin{array}{l}\mathrm{CO}_{2} \text { atmospheric } \\
\text { concentration used } \\
\text { in JULES (ppm) }\end{array}$ & References \\
\hline $\begin{array}{l}\text { University of } \\
\text { Michigan Bio- } \\
\text { logical Station } \\
\text { (UMBS), USA } \\
45.5^{\circ} \mathrm{N} \\
84.7^{\circ} \mathrm{W}\end{array}$ & $\begin{array}{l}\text { May } 2000 \text { to } \\
\text { October } 2002 \\
(\sim 5 \text { months } \\
\text { every year) }\end{array}$ & $\begin{array}{l}\text { Temperate } \\
\text { deciduous } \\
\text { broadleaf } \\
\text { forest }\end{array}$ & $\begin{array}{l}\text { Broadleaf } \\
\text { trees }\end{array}$ & $\begin{array}{l}\text { Populus } \\
\text { grandidentata, } \\
\text { P. tremuloides, } \\
\text { Fagus grandi- } \\
\text { folia, Betula } \\
\text { papyrifera, } \\
\text { Acer rubrum, } \\
\text { A. saccharum, } \\
\text { Quercus rubra, } \\
\text { Pinus strobus, } \\
\text { Pteridium } \\
\text { aquilium }\end{array}$ & & 45 & 369 & $\begin{array}{l}\text { Pressley et } \\
\text { al. (2005) }\end{array}$ \\
\hline $\begin{array}{l}\text { Harvard Forest, } \\
\text { Massachusetts, } \\
\text { USA } \\
42.5^{\circ} \mathrm{N} \\
72.2^{\circ} \mathrm{W}\end{array}$ & $\begin{array}{l}\text { May to } \\
\text { November } \\
1995 \\
\text { (160 days) }\end{array}$ & $\begin{array}{l}\text { Temperate } \\
\text { deciduous } \\
\text { broadleaf } \\
\text { forest }\end{array}$ & $\begin{array}{l}\text { Broadleaf } \\
\text { trees }\end{array}$ & $\begin{array}{l}\text { Quercus rubra, } \\
\text { Acer rubrum, } \\
\text { Pinus strobus, } \\
\text { Betula lenta, } \\
\text { Tsuga } \\
\text { canadensis, } \\
\text { Castanea } \\
\text { dentata }\end{array}$ & & 45 & 360 & $\begin{array}{l}\text { Goldstein } \\
\text { et al. (1998) } \\
\text { Müller et } \\
\text { al. (2008) }\end{array}$ \\
\hline $\begin{array}{l}\text { La Verdière, } \\
\text { France } \\
43.6^{\circ} \mathrm{N} \\
6.0^{\circ} \mathrm{E}\end{array}$ & $\begin{array}{l}\text { June-July } 2000 \\
(\sim 14 \text { days })\end{array}$ & $\begin{array}{l}\text { Temperate } \\
\text { deciduous } \\
\text { broadleaf } \\
\text { forest }\end{array}$ & $\begin{array}{l}\text { Broadleaf } \\
\text { trees }\end{array}$ & $\begin{array}{l}\text { Quercus } \\
\text { pubescens }\end{array}$ & 24.2 & 45 & 368 & $\begin{array}{l}\text { Dominique } \\
\text { Serça, } \\
\text { unpublished } \\
\text { data }\end{array}$ \\
\hline $\begin{array}{l}\text { Montmeyan, } \\
\text { France } \\
43.6^{\circ} \mathrm{N} \\
6.1^{\circ} \mathrm{E}\end{array}$ & $\begin{array}{l}\text { June } 2001 \\
(\sim 13 \text { days })\end{array}$ & $\begin{array}{l}\text { Temperate } \\
\text { deciduous } \\
\text { broadleaf } \\
\text { forest }\end{array}$ & $\begin{array}{l}\text { Broadleaf } \\
\text { trees }\end{array}$ & $\begin{array}{l}\text { Quercus } \\
\text { pubescens }\end{array}$ & 37.2 & 45 & 369 & $\begin{array}{l}\text { Dominique } \\
\text { Serça, } \\
\text { unpublished } \\
\text { data }\end{array}$ \\
\hline $\begin{array}{l}60 \mathrm{~km} \text { NNW of } \\
\text { Manaus, Brazil } \\
2.6^{\circ} \mathrm{S} \\
60.2^{\circ} \mathrm{W}\end{array}$ & $\begin{array}{l}\text { September } \\
2004 \\
(\sim 9 \text { days })\end{array}$ & $\begin{array}{l}\text { Tropical } \\
\text { rain forest }\end{array}$ & $\begin{array}{l}\text { Broadleaf } \\
\text { trees }\end{array}$ & & & 24 & 376 & $\begin{array}{l}\text { Karl et al. } \\
\text { (2007) }\end{array}$ \\
\hline $\begin{array}{l}\text { Santarem km } \\
67, \text { Brazil } \\
2.9^{\circ} \mathrm{S} \\
55.0^{\circ} \mathrm{W}\end{array}$ & $\begin{array}{l}\text { October- } \\
\text { November } \\
2003 \\
\text { (15 days) }\end{array}$ & $\begin{array}{l}\text { Tropical } \\
\text { rain forest }\end{array}$ & $\begin{array}{l}\text { Broadleaf } \\
\text { trees }\end{array}$ & & & 24 & 375 & $\begin{array}{l}\text { Müller et } \\
\text { al. (2008) }\end{array}$ \\
\hline
\end{tabular}

the simulated isoprene emissions. The gap-filled values were compared with the actual observations at the site, when available, and in no case did this procedure introduce a radical departure from the observed variable changes through the day. The number of data points averaged for gap filling depends mainly on the site (the more years of data the more years available for averaging). The proportion of gap-filled temperature and radiation data was always less than $10 \%$ of the available data.

We quantified how well the model reproduces the magnitude, diurnal and day-to-day variability of the observations using linear correlation of hourly emissions, daily average emissions and daily maximum emissions. We also evaluated the simulated seasonal cycle of isoprene emissions against observations from the UMBS and the Harvard forest sites.
The correlations were calculated only for the hours when observations were made at each site.

\subsection{Evaluation strategy against satellite derived estimates}

Satellite observations of formaldehyde (HCHO) have been used to estimate biogenic isoprene emissions at a regional and global scale (e.g., Shim et al., 2005; Palmer et al., 2003, 2006; Fu et al., 2007; Barkley et al., 2008, 2009). In this study, we use HCHO-derived isoprene estimates over east and south Asia between 1996 and 2001 (Fu et al., 2007) and tropical South America between 1997 and 2001 (Barkley et al., 2008). 
We focus on tropical regions for evaluation against satellite-derived data because of the assumed importance of tropical areas as an isoprene source (Guenther et al., 2006), and because the two tropical flux-tower sites only provide short-term measurements and thus there is no other source of data about changes over the seasonal cycle at the tropics. We have selected satellite-derived isoprene estimates where the potential contribution of biomass burning to $\mathrm{HCHO}$ has been constrained: Fu et al. (2007) used local reports of annual burning along with satellite fire counts, while Barkley et al. (2008) used Along Track Scanning Radiometer (ATSR) fire counts and GOME $\mathrm{NO}_{2}$ columns to estimate the impact of biomass burning on HCHO. For east and south Asia in summer, Fu et al. (2007) found that the interference to isoprene estimates due to $\mathrm{HCHO}$ produced by anthropogenic VOC is small. Both studies use the Global Ozone Monitoring Experiment (GOME) satellite observations of $\mathrm{HCHO}$ and the GEOS-Chem chemistry transport model. The east and south Asia data set provides an average annual emission based on the period 1996 and 2001. The tropical South America data set records monthly mean isoprene emissions at the satellite overpass time (i.e. between 10:00 to 12:00 a.m. local time). Both data sets can be used to evaluate spatial patterns and the magnitude of total isoprene emissions; but only the South America data set can be used to evaluate the seasonal cycle and year-to-year variability of emissions.

The errors associated with estimating emissions from remotely-sensed $\mathrm{HCHO}$ are typically of the order $100 \%$ and predominately originate from errors in (a) the HCHO slant column retrieval, (b) the air-mass factor calculation (which converts the slant to a vertical column) and (c) uncertainties in the simplified representation of isoprene oxidation chemistry within the chemistry transport model (CTM; Barkley et al., 2008). Although the uncertainties of these estimates are large they are nevertheless still comparable to the uncertainties of estimates derived from an inventory approach.

For comparison with the satellite-based estimates of isoprene emission, we ran the model globally at half-degree resolution with a one-hour time step from 1990 to 2001 using meteorological inputs from the Integrated Project Water and Global Change (WATCH) Forcing Data (WFD; Weedon et

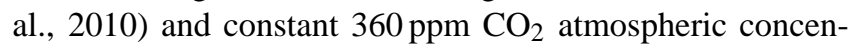
tration.

The WFD data are available at half-degree resolution over land (excluding Antarctica). However, downward longwave radiation, air pressure, specific humidity, air temperature, and wind speed are only provided at 6-hourly time steps, together with code to allow variable-specific interpolation to 3hourly time steps, and downward shortwave radiation, rainfall and snowfall are only provided at 3-hourly time steps. The data were interpolated, by the model itself, to the 1-h time step required by the model. The 1-h interpolation used here was variable specific. Air pressure, specific humidity, air temperature and wind speed were linearly interpolated, while downward longwave and shortwave radiation, rainfall and snowfall were interpolated forward with time (Clark et al., 2011).

The distribution of PFTs in this simulation is based on the International Geosphere-Biosphere Programme (IGBP) dataset (Loveland et al., 2000). The 17 land cover classes in this dataset were translated into proportional cover and characteristics of the five JULES PFTs and the proportional cover of the four non-vegetation JULES land cover types according to the scheme shown in Table 2. PFT distribution is kept fixed over the simulated time period but the phenological status of LAI is simulated for each PFT. IEFs values were derived from Guenther et al. (1995) and are: $35 \mu \mathrm{gC} \mathrm{gdw}{ }^{-1} \mathrm{~h}^{-1}$ for broadleaf trees; $12 \mu \mathrm{gC} \mathrm{gdw}{ }^{-1} \mathrm{~h}^{-1}$ for needleleaf trees; $16 \mu \mathrm{gCgdw}{ }^{-1} \mathrm{~h}^{-1}$ for $\mathrm{C}_{3}$ grass; $8 \mu \mathrm{gCgdw}^{-1} \mathrm{~h}^{-1}$ for $\mathrm{C}_{4}$ grass and; $20 \mu g \mathrm{gdw}^{-1} \mathrm{~h}^{-1}$ for shrubs. We extracted the simulated emissions for the same areas and spatial resolutions as in the satellite-derived emission estimates. We compared simulated against satellite-derived isoprene emissions in magnitude and spatial variability, seasonal and interannual variability are also evaluated when available. We only consider emissions over land as our scheme focuses on isoprene emission and does not include simulation of lateral transport.

We have also estimated global isoprene emissions from 1990 to 1999 based on the global simulation described above. These estimates are compared with previous model-derived estimates from the literature.

\section{Results}

\subsection{Model evaluation against ground-based isoprene flux measurements}

Simulated total daily isoprene emissions are always higher than observations (Table 3). Using the generic IEF from Guenther et al. (1995), the model overestimates the total daily isoprene emissions by a maximum of $236 \%$ at $\mathrm{La}$ Verdière. The use of a locally measured IEF instead of the generic IEF improves the magnitude of simulated emissions at La Verdière, but it has only a small impact on the magnitude of isoprene emissions at Montmeyan, where locally measured IEF and generic IEF are more similar to each other than at La Verdière (Table 1).

The coupled model generally reproduces the trend of the observed diurnal cycle of isoprene emissions (Fig. 1). In addition, the model correctly reproduces the onset of emissions, except at Manaus where modelled emissions start one hour (1 time step in the model) after observed emissions. Simulated emissions continue for up to two hours after observed emissions cease. The time of peak emission is correctly simulated at the UMBS site, but is delayed by between 1 (e.g., see Montmeyan in Fig. 1) and 3 h (e.g., see Manaus in Fig. 1) at the other sites. The magnitude of emissions during the early part of the day is correctly simulated, but simulated 
Table 2. Conversion of IGBP land cover classes into JULES fractions of surface types.

\begin{tabular}{|c|c|c|c|c|c|c|c|c|c|}
\hline \multirow[b]{2}{*}{ IGBP description } & \multicolumn{9}{|c|}{ Fractions of JULES surface types } \\
\hline & Broadleaf trees & Needleleaf trees & $\mathrm{C}_{3}$ grass & $\mathrm{C}_{4}$ grass & Shrubs & Urban & Water & Bare Soil & Ice \\
\hline Evergreen Needleleaf Forest & 0.0 & 69.3 & 22.2 & 0.0 & 0.0 & 0.0 & 0.0 & 8.4 & 0.0 \\
\hline Evergreen Broadleaf Forest & 85.9 & 0.0 & 0.9 & 7.0 & 0.0 & 0.0 & 0.0 & 6.2 & 0.0 \\
\hline Deciduous Needleleaf Forest & 0.0 & 65.3 & 25.6 & 0.0 & 0.0 & 0.0 & 0.0 & 9.1 & 0.0 \\
\hline Deciduous Broadleaf Forest & 62.4 & 0.0 & 7.0 & 8.9 & 3.7 & 0.0 & 0.0 & 18.1 & 0.0 \\
\hline Mixed Forest & 35.5 & 35.5 & 20.9 & 0.0 & 0.0 & 0.0 & 0.0 & 8.2 & 0.0 \\
\hline Closed Shrubs & 0.0 & 0.0 & 25.0 & 0.0 & 60.0 & 0.0 & 0.0 & 15.0 & 0.0 \\
\hline Open Shrubs & 0.9 & 0.0 & 3.1 & 14.7 & 34.2 & 0.0 & 0.0 & 47.2 & 0.0 \\
\hline Woody Savannah & 50.0 & 0.0 & 15.0 & 0.0 & 25.0 & 0.0 & 0.0 & 10.0 & 0.0 \\
\hline Savannah & 20.0 & 0.0 & 0.0 & 75.0 & 0.0 & 0.0 & 0.0 & 5.0 & 0.0 \\
\hline Grass Land & 0.0 & 0.0 & 66.0 & 15.7 & 4.9 & 0.0 & 0.0 & 13.5 & 0.0 \\
\hline Permanent Wet Land & 2.2 & 0.0 & 80.9 & 0.0 & 1.4 & 0.0 & 15.0 & 0.6 & 0.0 \\
\hline Cropland & 0.1 & 0.0 & 66.0 & 3.4 & 0.2 & 0.0 & 0.0 & 20.4 & 0.0 \\
\hline Urban & 0.0 & 0.0 & 0.0 & 0.0 & 0.0 & 100.0 & 0.0 & 0.0 & 0.0 \\
\hline Crop/Natural Mosaic & 5.0 & 5.0 & 55.0 & 15.0 & 10.0 & 0.0 & 0.0 & 10.0 & 0.0 \\
\hline Snow and Ice & 0.0 & 0.0 & 0.0 & 0.0 & 0.0 & 0.0 & 0.0 & 0.0 & 100.0 \\
\hline Barren & 0.0 & 0.0 & 0.0 & 0.0 & 0.0 & 0.0 & 0.0 & 100.0 & 0.0 \\
\hline Water Bodies & 0.0 & 0.0 & 0.0 & 0.0 & 0.0 & 0.0 & 100.0 & 0.0 & 0.0 \\
\hline
\end{tabular}

Table 3. Observed and simulated average total diurnal budget of isoprene emissions at the flux tower sites listed in Table 1.

\begin{tabular}{lccc}
\hline Site & $\begin{array}{c}\text { Observed average total diurnal } \\
\text { budget of isoprene emissions } \\
\left(\mathrm{mgC} \mathrm{m}^{-2} \mathrm{day}^{-1}\right)\end{array}$ & $\begin{array}{c}\text { Simulated average total diurnal } \\
\text { budget of isoprene emissions with local IEFs } \\
\left(\mathrm{mgC} \mathrm{m}^{-2} \mathrm{day}^{-1}\right)\end{array}$ & $\begin{array}{c}\text { Simulated average total diurnal } \\
\text { budget of isoprene emissions with IEFs } \\
\text { from Guenther et al. }(1995)\left(\mathrm{mgC} \mathrm{m}^{-2} \mathrm{day}^{-1}\right)\end{array}$ \\
\hline UMBS & 29 & & 63 \\
Harvard Forest & 30 & 57 & 50 \\
La Verdière & 28 & 115 & 94 \\
Montmeyan & 57 & & 125 \\
Manaus & 34 & & 102 \\
Santarem & 21 & & 56 \\
\hline
\end{tabular}

emissions in the middle of the day and in the afternoons are generally higher than observed.

The model overestimates observed hourly emissions at all sites except at the Harvard forest, using either the generic or the locally-derived IEF (Fig. 2). Hourly emissions are less well simulated at the Manaus and the Santarem sites, where (as stated above) simulated emissions are generally too high in the middle of the day and in the afternoons (Fig. 1). Correlation coefficients for hourly emissions are between 0.41 and 0.68 (all values significant at $95 \%$ level) across the sites (Fig. 2).

The model generally overestimates daily average emissions at all sites except at the Harvard forest (Fig. 3). The correlation coefficients for daily average emissions at each site vary between 0.31 and 0.84 (all significant at the $95 \%$ level, except those at La Verdière) across the sites (Fig. 3). The model generally overestimates daily maximum emissions at all sites (Fig. 4). The use of locally-derived IEF significantly improves the magnitude of simulated peak emissions at La
Verdière (Fig. 4). The correlation coefficients for daily maximum emissions vary between 0.08 and 0.76 (all significant at the $95 \%$ level, except those at La Verdière and Manaus) across all sites (Fig. 4).

Both the observations and simulations at the UMBS site (Fig. 5) show a similar seasonal pattern, with emissions starting in May, increasing rapidly through May and June and reaching their maximum values during June, July and August. As observed previously simulated emissions are generally higher than the observed ones. Despite LAI being better simulated in 2000 than in 2002, the onset of emissions is less well simulated in 2000 than in 2002: simulated emissions start ca. 20 days earlier than observed, albeit at a low rate (Fig. 5). The model reproduces the observed decline in emissions during the autumn but simulated emissions continue for 20-30 days longer than shown by the observations. The onset of leaf fall is well simulated in both years, but the interval over which leaf fall occurs is not well simulated. During autumn 2000 simulated LAI is high for longer than 


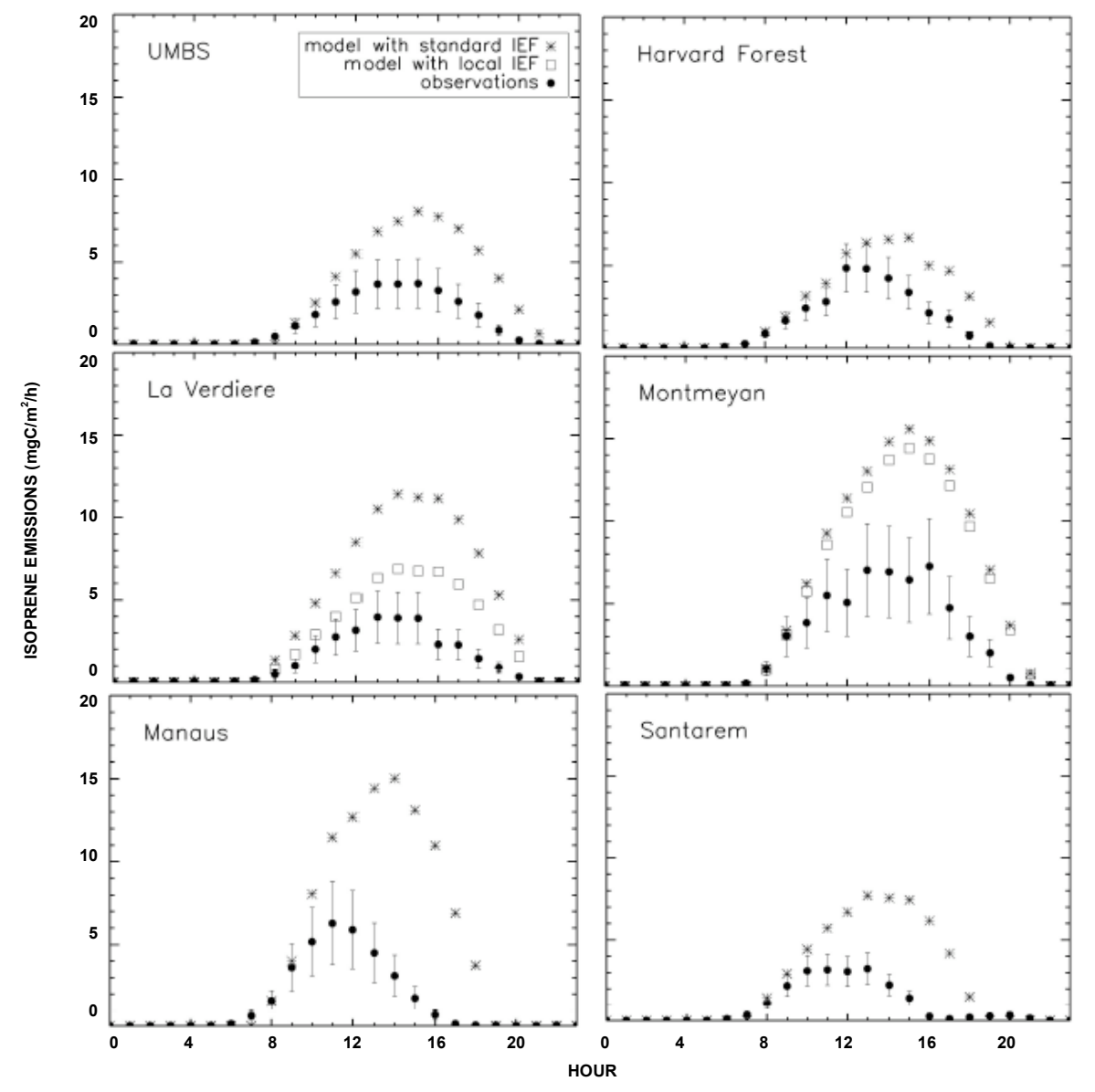

Fig. 1. Comparison of simulated and ground-based measured mean diurnal cycles of isoprene emissions at the flux tower sites listed in Table 1. Isoprene emissions were simulated using standard IEFs from Guenther et al. (1995) and local IEFs when available.

observed, which could explain why simulated isoprene emissions continue for longer than shown by observations. Leaf fall is completed more rapidly than observed in 2002, but this does not explain simulated isoprene emissions continuing for longer over autumn compared to observations. The model overestimates LAI magnitude over the mid-summer period, with simulated emissions $43 \%$ higher than observed ones. Despite the bigger number of missing data for the observations compared to the UMBS data set, similar results are found for the Harvard forest site: the model reproduces the observed seasonal cycle in magnitude, but it shows a longer seasonal cycle with simulated emissions starting too early in spring and continuing too long over autumn (not shown here).

\subsection{Model evaluation against satellite derived estimates}

Satellite-derived total annual mean isoprene emissions over east and south Asia $\left(12^{\circ} \mathrm{S}-55^{\circ} \mathrm{N}, 70^{\circ} \mathrm{E}-150^{\circ} \mathrm{E}\right)$ averaged over the years 1996-2001 have been estimated as $50 \mathrm{TgC} \mathrm{yr}^{-1}$, with an uncertainty of $26 \mathrm{TgC} \mathrm{yr}^{-1}$ (Fu et al.,
2007), compared to a simulated value of $83 \mathrm{TgC} \mathrm{yr}^{-1}$ on average over the $6 \mathrm{yr}$ simulation period (standard deviation over

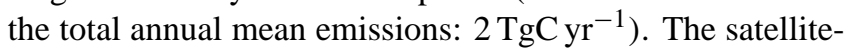
derived spatial distribution of the emissions over east and south Asia shows a gradient from low emissions in the northwest, which is mostly deserts and mountains, to high emissions in the south and east (Fig. 6). This pattern is also apparent in the simulation but with a larger gradient (Fig. 6). The model reproduces the generally low emissions over India and the higher emissions over Indochina. Simulated emissions over Indonesia and Papua are higher than observed. The model produces lower emissions in northern China and into eastern Siberia than shown in the satellite-derived product.

Satellite-derived area-weighted total isoprene emissions over tropical South America are $24.3 \mathrm{gC} \mathrm{m}^{-2}$ (standard deviation: $0.6 \mathrm{gC} \mathrm{m}^{-2}$ ) compared to a simulated value of $40.9 \mathrm{gC} \mathrm{m}^{-2}$ (standard deviation: $0.4 \mathrm{gC} \mathrm{m}^{-2}$ ). The trend of the simulated seasonal cycle over tropical South America is similar to the observed trend, but of higher magnitude (Fig. 7). Both satellite-derived and simulated emissions are higher from August to December (dry season) and generally 


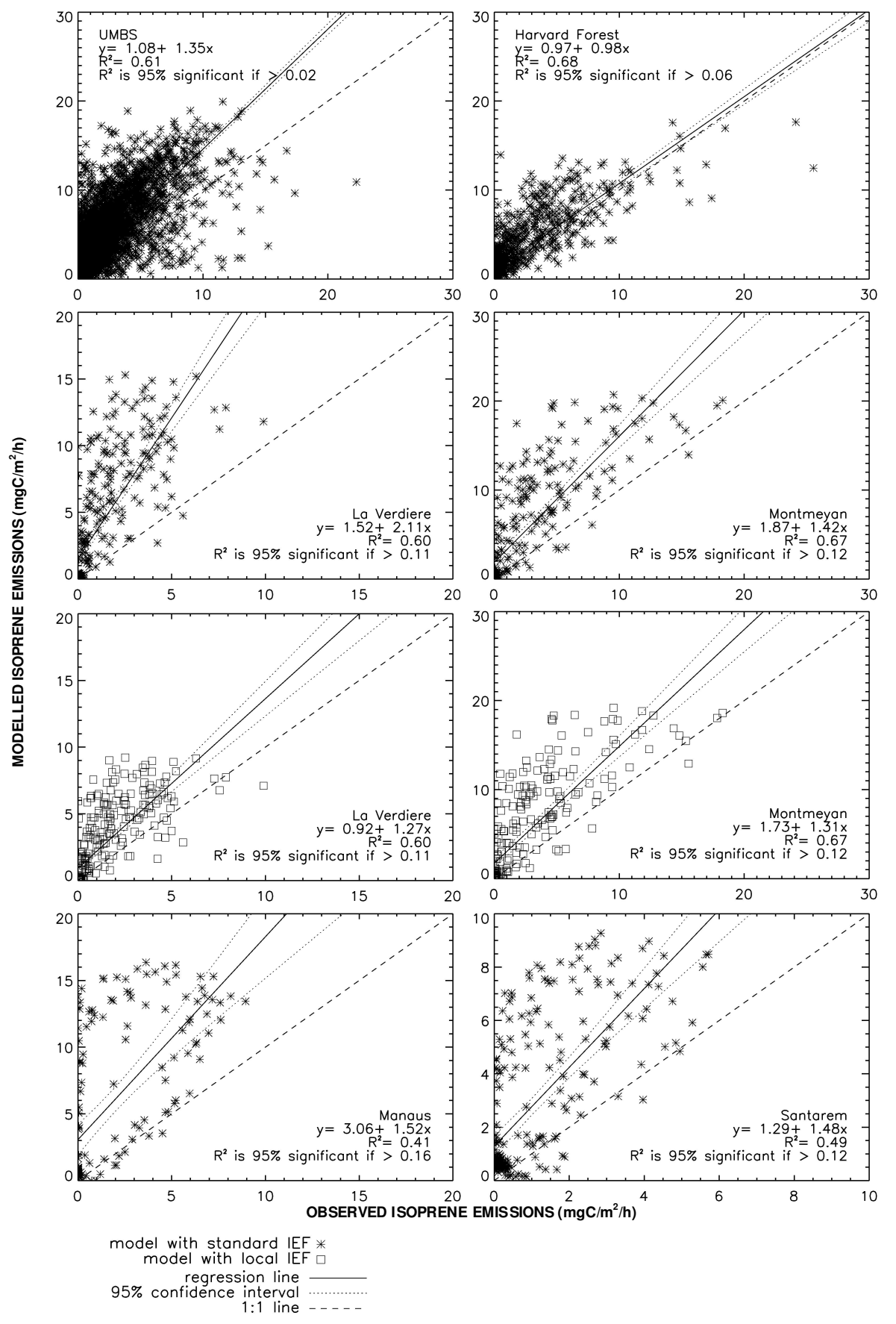

Fig. 2. Scatter plots of simulated and ground-based measured hourly isoprene emissions at the flux tower sites listed in Table 1 , including regression line, 95\% confidence interval (Scheffe's method) and 1:1 line. Isoprene emissions were simulated using standard isoprene emission factors (IEFs) from Guenther et al. (1995) and local IEFs when available (second row of figures).

lower from April to August (transition from the wet to the dry period). We define the wet and dry seasons as DecemberMay and August-November, as in Barkley et al. (2007). Inter-annual variability is larger in the satellite-derived estimates, which are derived from generally noisy $\mathrm{HCHO}$ satellite data (Barkley et al., 2008).
Spatial variability of isoprene emissions over tropical South America is broadly reproduced with emissions increasing from northern and western to central Amazonia. The model generally overestimates emissions especially over the north-eastern coast. Inter-annual spatial variability is larger in the satellite-derived estimates, which are also 


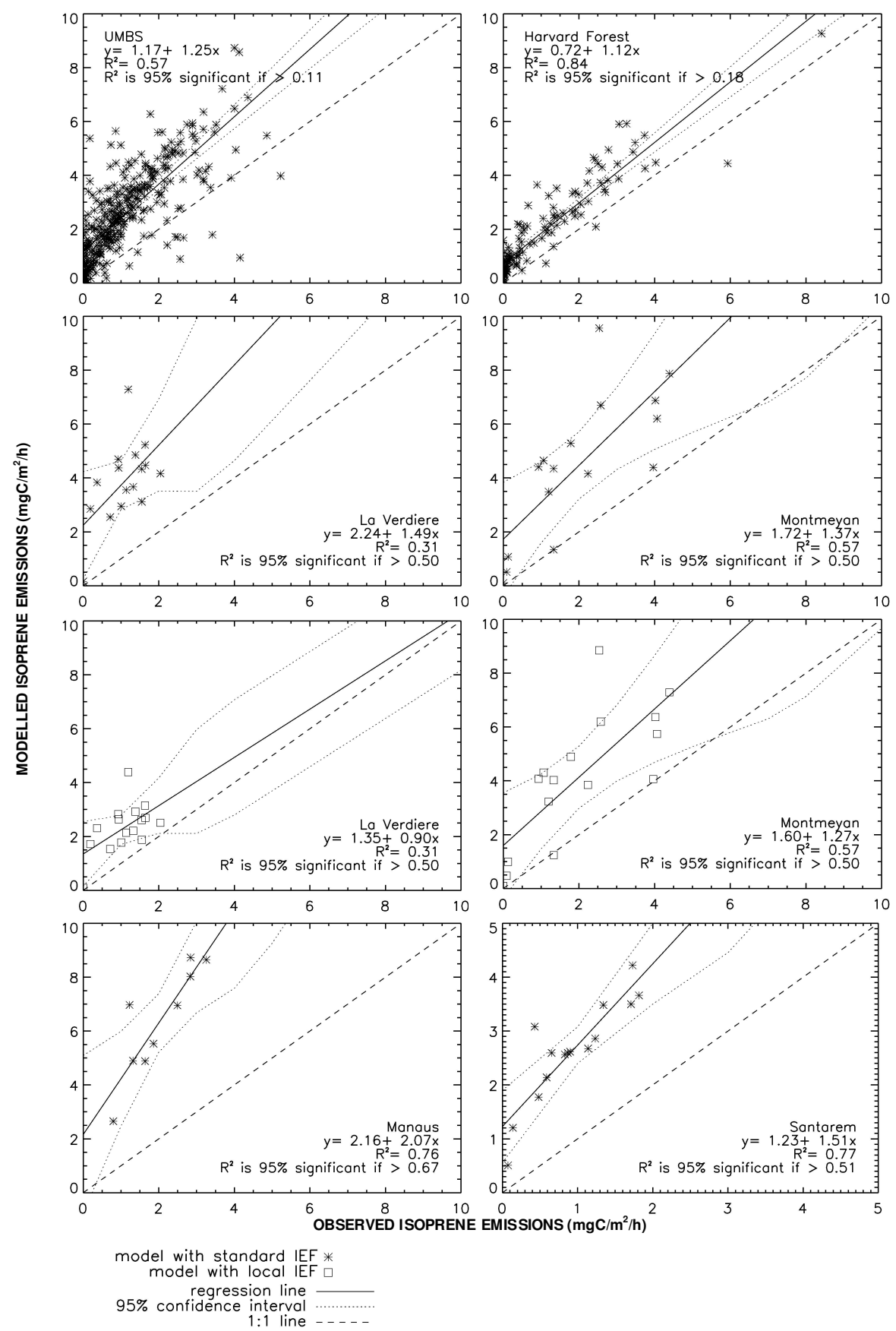

Fig. 3. Scatter plots of simulated and ground-based measured daily average isoprene emissions at the flux tower sites listed in Table 1, including regression line, $95 \%$ confidence interval (Scheffe's method) and 1:1 line. Isoprene emissions were simulated using standard isoprene emission factors (IEFs) from Guenther et al. (1995) and local IEFs when available (second row of figures).

noisier (see e.g. Fig. 8 for year 1999). Correlation coefficients for month-to-month variability are not significant.

\subsection{Isoprene emission global estimates}

Published estimates of annual global total isoprene emissions for present-day (based on different time periods between
1971 to 2003) range from 400 to $600 \mathrm{TgC}^{-1} r^{-1}$, with an average over the different studies of $516 \mathrm{TgC} \mathrm{yr}^{-1}$ (see Table 1 in Arneth et al., 2008a). Our annual global total estimate ranges between 516 and $552 \mathrm{TgC} \mathrm{yr}^{-1}$, with $535 \mathrm{TgC} \mathrm{yr}^{-1}$ averaged over the period 1990 to 1999; this is higher than the estimate obtained by Sanderson et al. (2003) for the same 

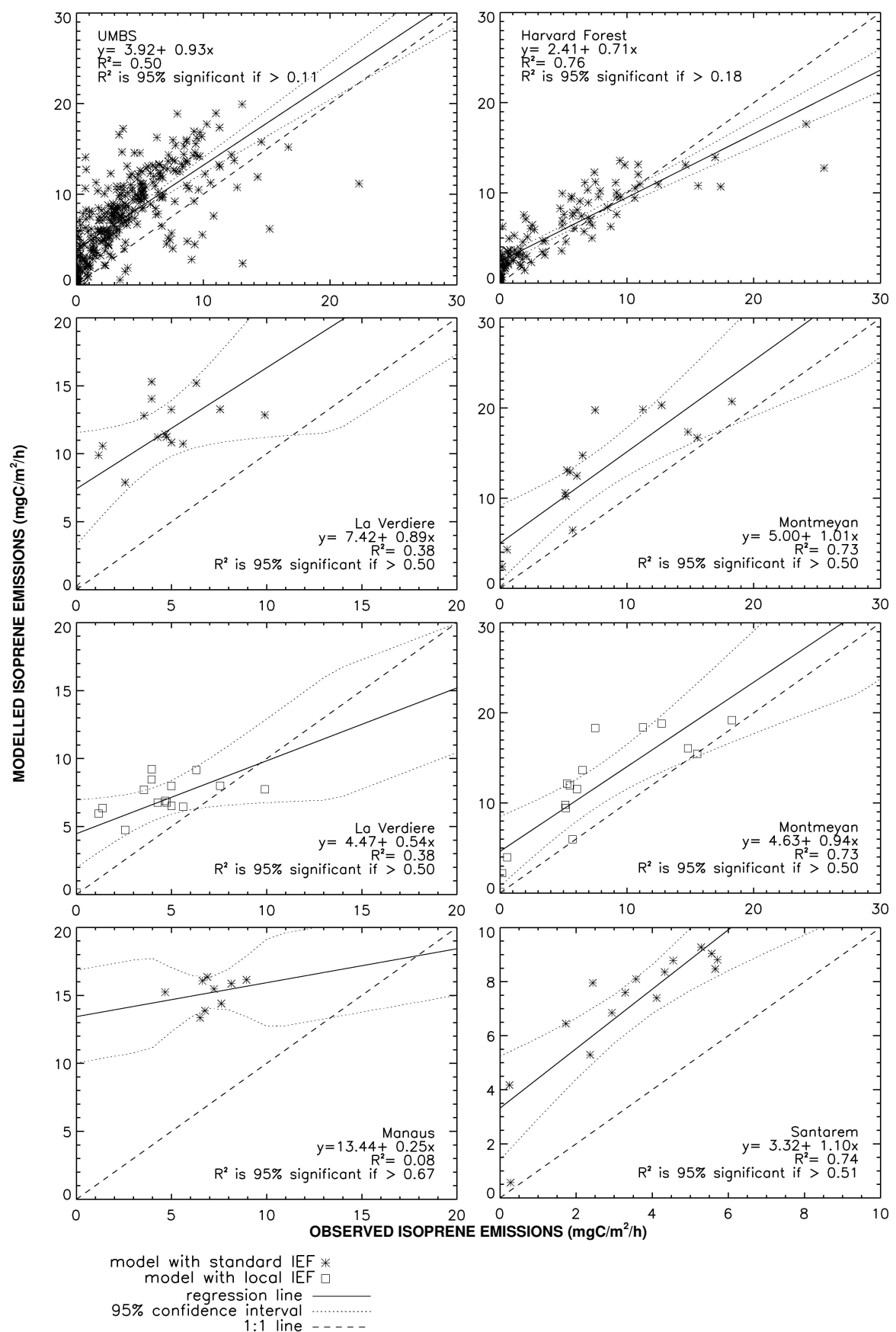

model with local IEF

$1: 1$ line

Fig. 4. Scatter plots of simulated and ground-based measured daily maximum isoprene emissions at the flux tower sites listed in Table 1, including regression line, $95 \%$ confidence interval (Scheffe's method) and 1:1 line. Isoprene emissions were simulated using standard isoprene emission factors (IEFs) from Guenther et al. (1995) and local IEFs when available (second row of figures).

decade ( $483 \mathrm{TgC} \mathrm{yr}^{-1}$ ) but falls inside the range of other estimates for present-day climate conditions (see Table 1 in Arneth et al., 2008a). The approach used to derive previous estimates vary from study to study; determining the underlying causes for differences between the various estimates would require analyses beyond the scope of the present paper. In our simulation, broadleaf trees make the largest contribution to global isoprene emissions ( $371 \mathrm{TgC}, 69 \%$ ), followed by $\mathrm{C}_{4}$ grass $(49 \mathrm{TgC}, 9 \%), \mathrm{C}_{3}$ grass $(47 \mathrm{TgC}, 9 \%)$, needleleaf trees $(47 \mathrm{TgC}, 9 \%)$ and shrubs $(21 \mathrm{TgC}, 4 \%)$. Broadleaf trees are also the most abundant PFT in JULES vegetation distribution maps (Fig. 10). 

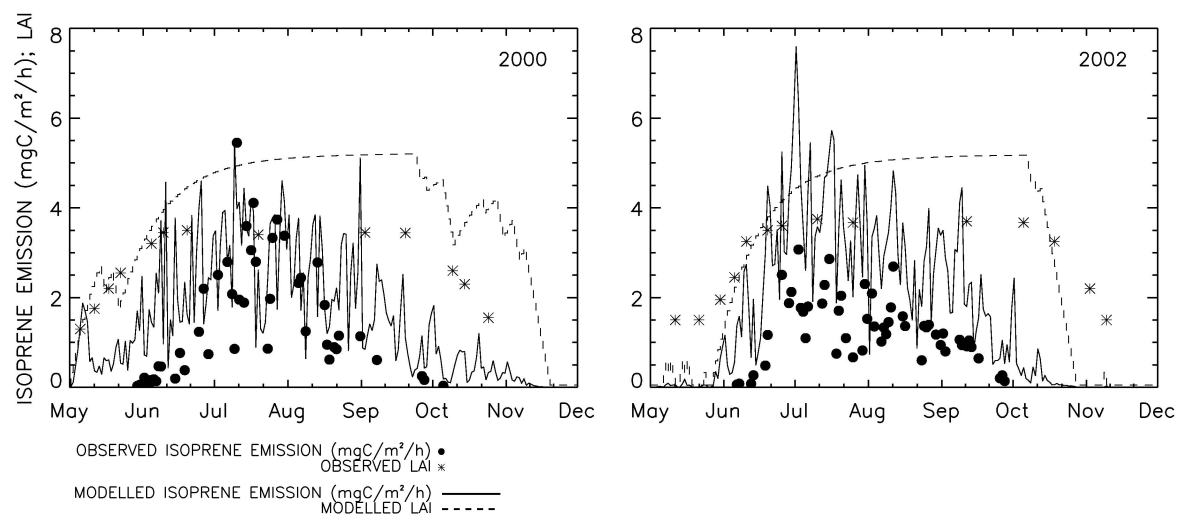

Fig. 5. Comparison of simulated and ground-based measured seasonal cycle of daily mean isoprene emissions (Pressley et al., 2005) and LAI (Pressley et al., 2006) at UMBS for 2000 and 2002.

Table 4. Sensitivity of total annual emissions to the specification of PFT-specific IEFs.

\begin{tabular}{lccc}
\hline PFTs & $\begin{array}{c}\text { IEFs }\left(\mu g C \mathrm{gdw}^{-1} \mathrm{~h}^{-1}\right) \\
\text { used in this study }\end{array}$ & $\begin{array}{c}\text { Total global annual isoprene emissions } \\
\text { averaged over the 1990s }\left(\mathrm{TgC} \mathrm{yr}^{-1}\right)\end{array}$ & $\begin{array}{c}\text { IEFs }\left(\mu g C \mathrm{gdw}^{-1} \mathrm{~h}^{-1}\right) \text { needed to achive total } \\
\text { global annual isoprene emissions of } 600 \mathrm{TgC} \mathrm{yr}^{-1}\end{array}$ \\
\hline Broadleaf trees & 35 & $371(69 \%)$ & 39 \\
Needledleaf trees & 12 & $47(9 \%)$ & 14 \\
C $_{3}$ grass & 16 & $47(9 \%)$ & 14 \\
$\mathrm{C}_{4}$ grass & 8 & $49(9 \%)$ & 23 \\
Shrubs & 20 & $21(4 \%)$ & 14 \\
Total over PFTs & & 535 & \\
\hline
\end{tabular}

The results from Arneth et al. (2007a) and Guenther et al. (2006) are based on different time periods (1981-2000 and 2003 respectively) from that covered by our simulation, and they both obtain lower estimates for the global total (410 $\mathrm{TgC} \mathrm{yr}^{-1}$ and $529 \mathrm{TgC} \mathrm{yr}^{-1}$, respectively) but nevertheless these results can be used to compare the first-order spatial patterns of emissions (Fig. 1 in Arneth et al., 2007a and Fig. 10 in Guenther et al., 2006). As in our simulation, both Arneth et al. (2007a) and Guenther et al. (2006) show the tropics as main source of isoprene (Fig. 9). We simulate lower emissions over South America and some European areas and less spatial variability over Amazonia than Arneth et al. (2007a), while emissions over tropical areas are similar in magnitude. We also simulate less isoprene emissions over Australia than Guenther et al. (2006).

We have studied the sensitivity of isoprene emissions to a change in the conversion factors from IGBP to JULES surface types (Table 2). A $10 \%$ increase/decrease on the dominant JULES PFT fraction for each IGBP land cover class (balanced by a correspondent decrease/increase over the remaining PFT fractions) results in a $10-12 \%$ increases/decrease in annual global total isoprene emissions. Mapping from observed biomes to model-specific PFTs is likely to be at least this uncertain and hence we estimate an uncertainty of $\pm 50 \mathrm{TgC} \mathrm{yr}^{-1}$ in isoprene emission due to uncertainty in representation of land-cover.
One of the greatest uncertainties in modelling the global emission of isoprene is the use of generic PFT-dependent IEFs. We have calculated the IEFs we would need to use to achieve $600 \mathrm{TgC} \mathrm{yr}^{-1}$ (i.e. the higher published estimate of global isoprene emissions for present-day; Arneth et al., 2008a), keeping the relative proportion of emissions between PFTs constant and without changes to the model (see Table 4). The emission factors required to achieve a global total emission of $600 \mathrm{TgC} \mathrm{yr}^{-1}$ are within the observed range of species-level IEFs measurements (Hewitt and Street, 1992; Wiedinmyer et al., 2004) for each of the model PFTs.

Inter-annual variability of global total isoprene emissions is correlated with global temperature anomalies (Fig. 11). The 1992 minimum in isoprene emissions is associated with reduced radiation and cooler and drier conditions following Mt. Pinatubo eruption in 1991 (also observed in Telford et al., 2010). The maximum in isoprene emissions occurs during the warm phases of the El-Niño Southern Oscillation (ENSO) in 1997-1998.

\section{Discussion and conclusions}

We have coupled the Arneth et al. (2007b) isoprene emission scheme into the JULES land-surface scheme and shown that the coupled model is able to reproduce the main features of 

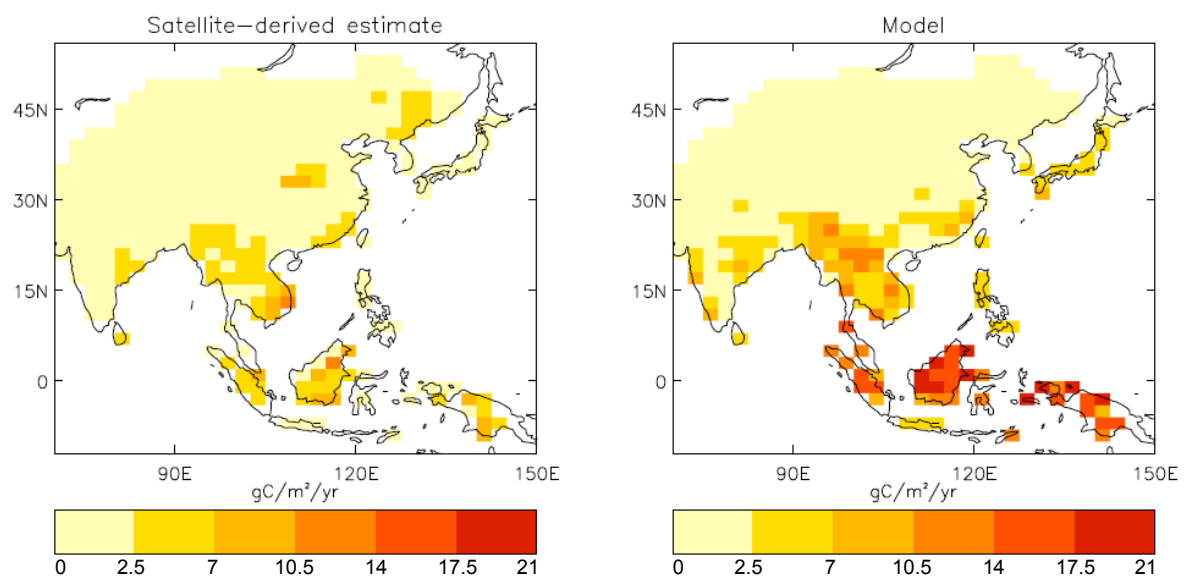

Fig. 6. Comparison of spatial patterns of simulated and satellite-derived total annual isoprene emissions over east and south Asia averaged over 1996 to 2001.
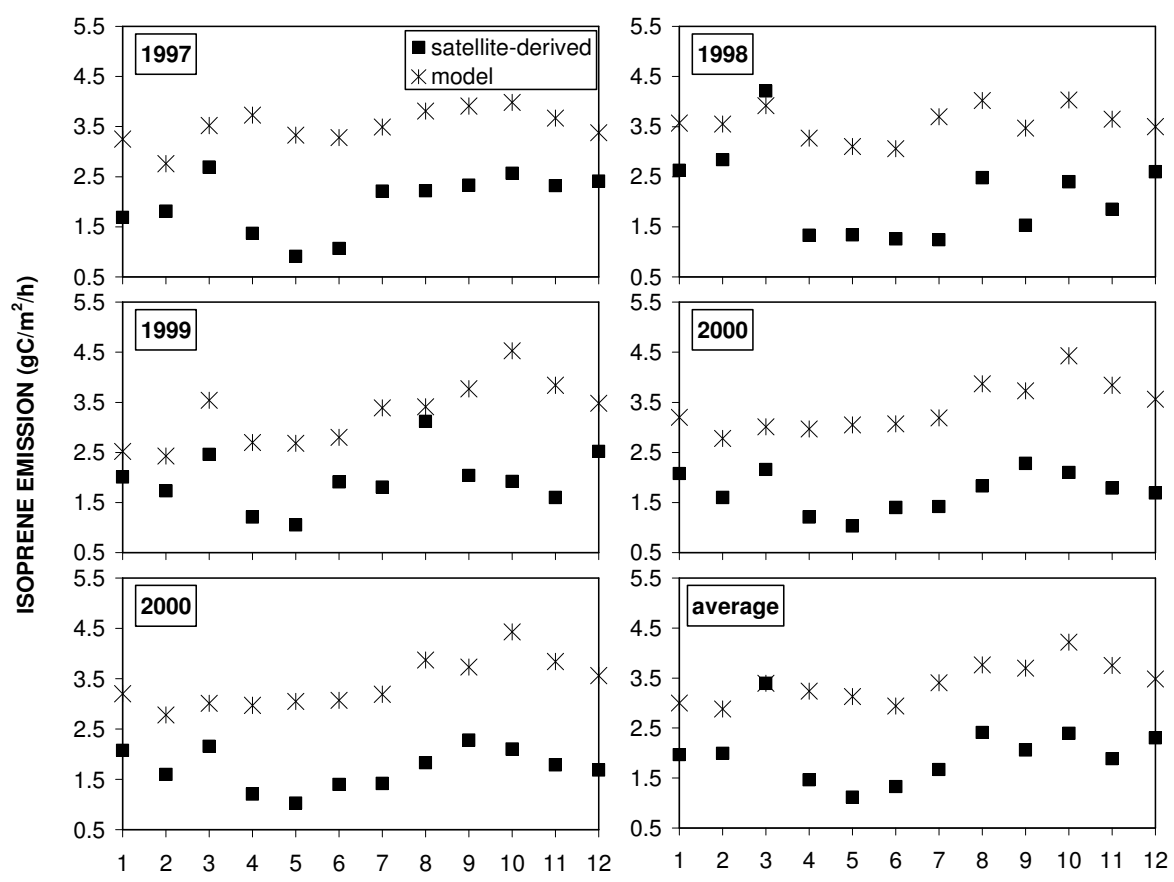

Fig. 7. Comparison of simulated and satellite-derived monthly total isoprene emissions (10:00-12:00 LT) over tropical South America for individual years from 1997 to 2001, May to November.

the diurnal cycle, daily variability and seasonal cycle of isoprene emissions. The model overestimates observed emissions for all sites, which is partially due to the fact that we do not include isoprene loss through the canopy. Only a fraction of isoprene emitted by leaves reaches the canopy because of biological, chemical and physical processes on soil and vegetation surfaces, and chemical reactions within the canopy atmosphere. There have been few estimates of this loss, but it is generally accepted that it is $<10 \%$ of the total emission (Karl et al., 2004; Stroud et al., 2005). Comparison with satellite-derived estimates of isoprene emissions shows that the model also simulates the spatial patterns of emission in tropical areas, although it is less good at reproducing magnitude and year-to-year variability in emissions in these regions (note the high uncertainty not only associated with the bottom-up modelling but also with the top-down satellite derived isoprene estimates).

We have used the rate of net photosynthesis as an approximation to the more mechanistically correct electron transport dependent rate of net photosynthesis (Niinemets et al., 1999) 


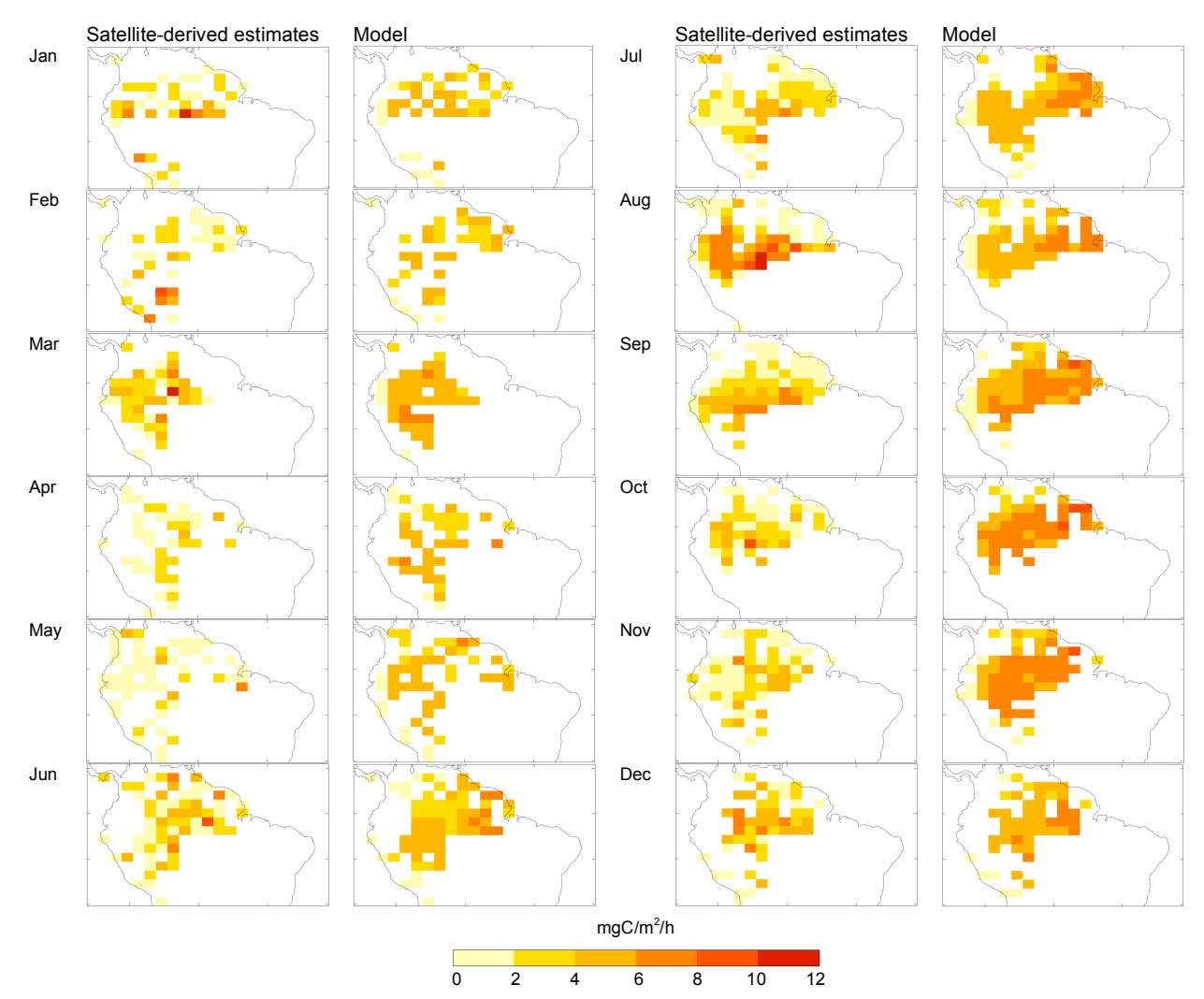

Fig. 8. Comparison of spatial patterns of simulated and satellite-derived monthly mean isoprene emissions (10:00-12:00 LT) over tropical South America for 1999.

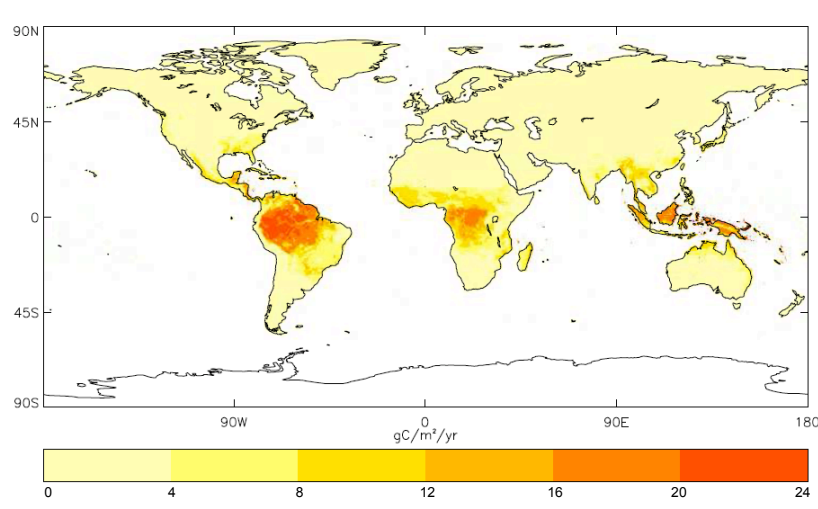

Fig. 9. Annual global simulation of isoprene emissions averaged over the 1990s.

because JULES does not simulate electron transport explicitly. The fact that we are able to reproduce observed patterns of isoprene emission suggests that this approximation is reasonable.

The simulated time of peak emission in the diurnal cycle of isoprene emission is delayed up to $3 \mathrm{~h}$ at the some sites (in particular tropical ones). This could be due to a too strong temperature adjustment in the model (i.e. $a_{T}$, Eq. 6). In the diurnal cycle maximum temperature and maximum photosynthesis are lagged, so a too strong temperature adjustment could keep emissions up even though photosynthesis has already begun to decline.

Some of the mismatches between our simulations and observed isoprene emissions could be due to problems with the simulated vegetation phenology in JULES. Simulated emissions in autumn 2000 at the UMBS site, for example, continue for nearly one month longer than observed and this is because the trees retain their leaves for longer than observed. Our ability to simulate the seasonal cycle of isoprene emissions, and hence the magnitude of the yearly emissions, is critically dependent on the phenology of individual PFTs as simulated by JULES. Improvements to, for example, the controls of leaf fall in JULES could produce a significant improvement in our estimates of isoprene emissions.

A limited number of measurements have shown that young leaves do not emit isoprene (Centritto et al., 2004) and there is a typical lag of a few weeks between the onset of photosynthesis and that of isoprene emissions (e.g., Wiberley et al., 2005). We do not take leaf age into consideration in the isoprene emission scheme, although this would be possible and could possibly explain the mismatch between well simulated isoprene onset and less well simulated LAI at the beginning 

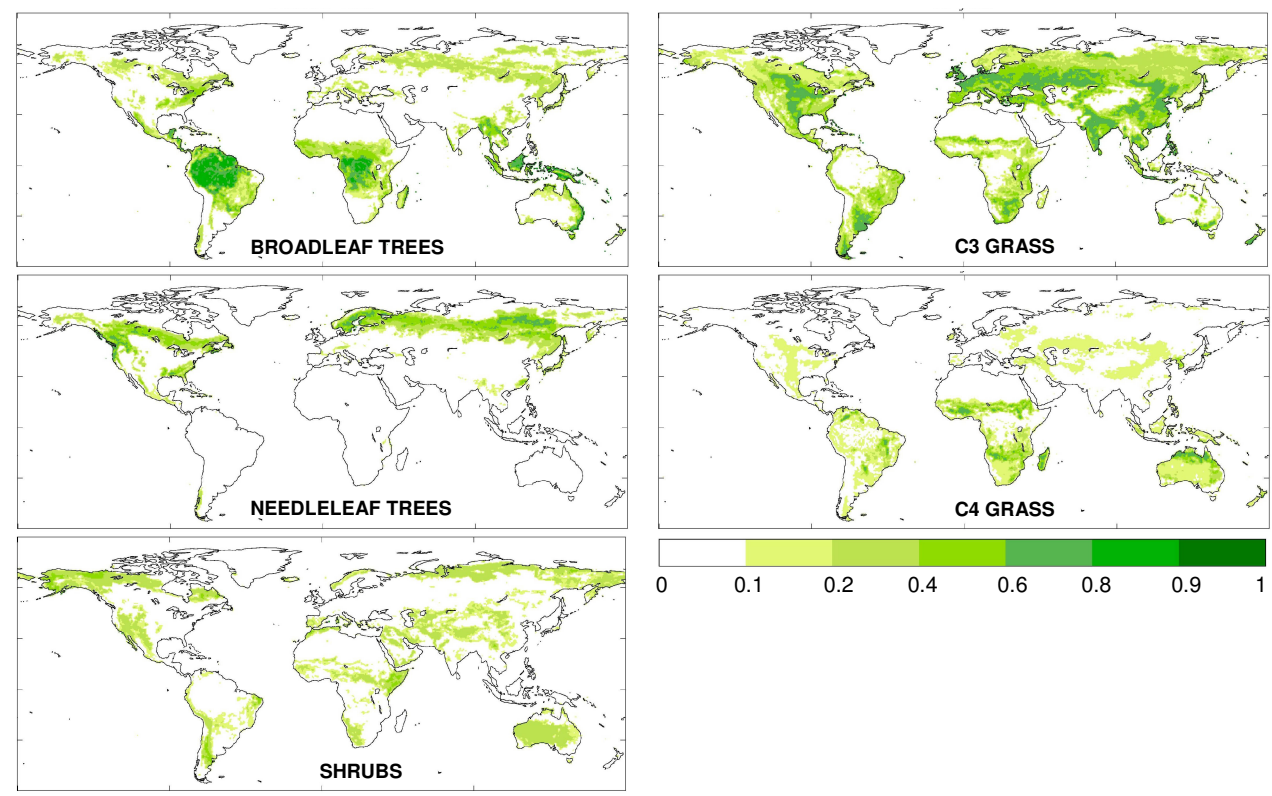

Fig. 10. Maps of the fraction of grid cell covered by each PFT as used in JULES.

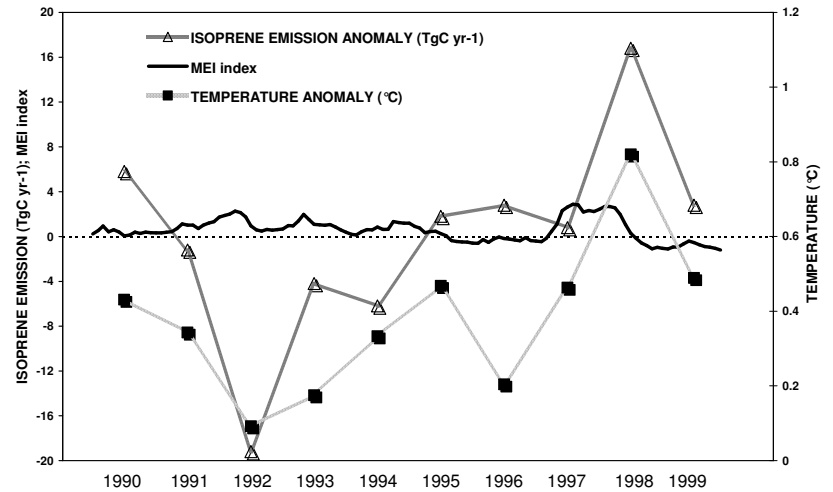

Fig. 11. Inter-annual variability of simulated global total isoprene emissions anomalies, global average land air temperature anomalies from the historical surface temperature dataset CRUTEM3 (Brohan et al., 2006) and Multivariate El Niño/Southern Oscillation (ENSO) Index (MEI; Wolter and Timlin, 1993, 1998) over the 1990s.

of the season, and vice versa (Fig. 5). Our limited evaluation of the onset of emissions at the UMBS and the Harvard forest sites does not provide enough guidance as to whether such a treatment is necessary. However, the lack of this mechanism in our simulations could be a possible explanation for the mismatch between modelled and satellite-derived isoprene emissions in the transition from the wet to the dry period over tropical South America. We have shown that using locally-derived IEFs instead of generic IEFs from Guenther et al. (1995) produced a better simulation of emissions in magnitude at one flux measurement sites (La Verdière), but yielded only a slight improvement in the other site where a locally measured IEF is available (Montmeyan). In models that parameterize individual tree species, like LPJ-GUESS, the use of species-specific emission factors has been shown to improve the simulation of isoprene emissions (Arneth et al., 2008a; Schurgers et al., 2009). The vegetation representation in JULES is much more generic, and at the regional scale (as shown by the comparisons with the HCHO-derived emissions) the model is able to reproduce the main features of isoprene spatial variability, but overestimates emissions in magnitude using the more general PFT-dependent IEFs from Guenther et al. (1995). This implies that the model could overestimate global isoprene emissions. At a local level the overestimation is reduced by the use of locally measured IEF in only one case out of two: despite the large uncertainties on IEF values and the fact that they have a strong impact on simulated emissions, our comparisons do not indicate that the use of local IEFs would significantly improve the simulations.

In our simulation broadleaf trees are the major contributors to total global emissions because they are the most abundant PFT in vegetation distribution maps (Fig. 10), they have the highest IEF and they are widely present in tropical areas where temperature and light conditions favour isoprene emissions. Despite their relatively high IEF, shrubs contribute little to total global emissions because of their smaller coverage in the PFT distribution map used to drive the simulations (Fig. 10).

We identify the tropics as the main source of isoprene, as do previous estimates (Arneth et al., 2007a; Guenther et al., 2006), but we generally simulate less spatial variability 
in emissions. The absence of isoprene "emission hotspots" in our simulations may explain the lower levels of tropical emissions. This, in turn, is likely to be related to the relatively simple PFT classification used in JULES. Where other models include both raingreen and evergreen broadleaf tropical trees (e.g. Arnethet al., 2007a), JULES has only one type of broadleaf tree in the tropics. The large uncertainty on PFTdependent IEFs implies that increasing the number of simulated PFTs in JULES would not make a large difference in the estimation of global isoprene emissions. We also show that our global total estimate of isoprene emissions is robust for reasonable variations in the conversion factors from IGBP to JULES surface types (Table 2).

Most of the isoprene emission flux measurements have been collected in tree-dominated biomes, as they are considered the main emitters (Guenther et al., 2006). Nevertheless observations collected at a grassland site in Inner Mongolia reach values comparable to a tree-dominated environment (Bai et al., 2006), while summer-time maxima in a sub-arctic Swedish wetland reach values similar to boreal and temperate forest locations (Holst et al., 2010). We have been unable to make a simulation for this these sites because of the lack of local meteorological data; in particular downward longwave and shortwave radiation were not available for a time period long enough to perform a local simulation. Our global simulations driven by the WATCH re-analysis meteorological data did not show any notable isoprene emissions over these areas. This might be due to the fact that in the global simulation we use generic IEFs that are not representative of the measurement site.

Our ability to evaluate the isoprene emission schemes is somewhat hampered by lack of data. There are very few above-canopy isoprene flux measurements available, and the existing studies sample a limited range of vegetation types. Additional studies on a range of different biomes and with measurements made for longer periods are necessary. Robust evaluation of model performance requires measurements over multiple years in order to validate the simulated seasonal cycle and to determine whether it is important to simulate the impact of leaf aging on isoprene emissions explicitly. Nevertheless, the current evaluation provides increased confidence in our ability to simulate isoprene emissions realistically at the global scale, and hence opens up the possibility of exploring and quantifying the feedbacks between biogenic emissions and climate more fully (e.g., Arneth et al., 2010), both in the context of studies of air quality and future climate change (e.g., Young et al., 2009) as well as for palaeoclimates (e.g., Valdes et al., 2005).

Acknowledgements. This paper is a contribution to the GREENCYCLES (MRTN-CT-2004512464) (FP, SPH, SS). This work has been partly funded by EUCAARI (European Integrated project on Aerosol Cloud Climate and Air Quality interactions) No. 036833-2. FP, CJ and GPW were supported by the Joint DECC/Defra Met Office Hadley Centre Climate Programme (GA01101). MPB was supported by the Natural Environment Research Council (grant
NE/D001471). AA and GS acknowledge support by the Swedish Research Councils Vetenskapsrådet and Formas. We thank Shelley Pressley for use of the UMBS isoprene flux measurements and Thomas Karl for the use of the Manaus isoprene flux measurements. We thank Lina Mercado, David Pearson, Emma Compton, Gerd Folberth, Doug McNeall and Richard Betts for their help.

Edited by: M. Kulmala

\section{References}

Arneth, A., Miller, P. A., Scholze, M., Hickler, T., Schurgers, G., Smith, B., and Prentice, I.C.: $\mathrm{CO}_{2}$ inhibition of global terrestrial isoprene emissions: potential implications for atmospheric chemistry, Geophys. Res. Lett., 34, L18813, doi:10.1029/2007GL030615, 2007a.

Arneth, A., Niinemets, Ü., Pressley, S., Bäck, J., Hari, P., Karl, T., Noe, S., Prentice, I. C., Serça, D., Hickler, T., Wolf, A., and Smith, B.: Process-based estimates of terrestrial ecosystem isoprene emissions: incorporating the effects of a direct $\mathrm{CO}_{2}$-isoprene interaction, Atmos. Chem. Phys., 7, 31-53, doi:10.5194/acp-7-31-2007, 2007b.

Arneth, A., Monson, R. K., Schurgers, G., Niinemets, Ü., and Palmer, P. I.: Why are estimates of global terrestrial isoprene emissions so similar (and why is this not so for monoterpenes)?, Atmos. Chem. Phys., 8, 4605-4620, doi:10.5194/acp-8-46052008, 2008a.

Arneth, A., Schurgers, G., Hickler, T., and Miller, P. A.: Effects of species composition, land surface cover, $\mathrm{CO}_{2}$ concentration and climate on isoprene emissions from European forests, Plant Biol., 9, 1-12, 2008b.

Arneth, A., Sitch, S., Bondeau, A., Butterbach-Bahl, K., Foster, P., Gedney, N., de Noblet-Ducoudré, N., Prentice, I. C., Sanderson, M., Thonicke, K., Wania, R., and Zaehle, S.: From biota to chemistry and climate: towards a comprehensive description of trace gas exchange between the biosphere and atmosphere, Biogeosciences, 7, 121-149, doi:10.5194/bg-7-121-2010, 2010.

Bai, J., Baker, B., Liang, B., Greenberg, J., and Guenther, A.: Isoprene and monoterpene emissions from an Inner Mongolia grassland, Atmos. Environ., 40, 5753-5758, 2006.

Barkley, M. P., Palmer, P. I., Kuhn, U., Kesselmeier, J., Chance, K., Kurosu, T. P., Martin, R. V., Helmig, D., and Guenther, A.: Net ecosystem fluxes of isoprene over tropical South America inferred from Global Ozone Monitoring Experiment (GOME) observations of HCHO columns, J. Geophys. Res., 113, D20304, doi:10.1029/2008JD009863, 2008.

Barkley, M. P., Palmer, P. I., De Smedt, I., Karl, T., Guenther, A., and Van Roozendael, M.: Regulated large-scale annual shutdown of Amazonian isoprene emissions?, Geophys. Res. Lett., 36, L04803, doi:10.1029/2008GL036843, 2009.

Best, M. J., Pryor, M., Clark, D. B., Rooney, G. G., Essery, R. L. H., Ménard, C. B., Edwards, J. M., Hendry, M. A., Porson, A., Gedney, N., Mercado, L. M., Sitch, S., Blyth, E., Boucher, O., Cox, P. M., Grimmond, C. S. B., and Harding, R. J.: The Joint UK Land Environment Simulator (JULES), Model description Part 1: Energy and water fluxes, Geosci. Model Dev. Discuss., 4, 595-640, doi:10.5194/gmdd-4-595-2011, 2011.

Blyth, E., Gash, J., Lloyd, A., Pryor, M., Weedon, G. P., and Shuttleworth, W. J.: Evaluating the JULES land surface model en- 
ergy fluxes using FLUXNET data, J. Hydrometeo., 11, 509-519, 2010.

Blyth, E., Clark, D. B., Ellis, R., Huntingford, C., Los, S., Pryor, M., Best, M., and Sitch, S.: A comprehensive set of benchmark tests for a land surface model of simultaneous fluxes of water and carbon at both the global and seasonal scale, Geosci. Model Dev., 4, 255-269, doi:10.5194/gmd-4-255-2011, 2011.

Brohan, P., Kennedy, J. J., Harris, I., Tett, S. F. B., and Jones, P. D.: Uncertainty estimates in regional and global observed temperature changes: a new dataset from 1850,J. Geophys. Res., 111, D12106, doi:10.1029/2005JD006548, 2006.

Cadule, P., Friedlingstein, P., Bopp, L., Sitch, S., Jones, C. D., Ciais, P., Piao, S. L., and Peylin, P.: Benchmarking coupled climate-carbon models against long-term atmospheric $\mathrm{CO}_{2}$ measurements, Global Biogeochem. Cy., 24, GB2016, doi:10.1029/2009GB003556, 2010.

Centritto, M., Nascetti, P., Petrilli, L., Raschi, A., and Loreto, F.: Profiles of isoprene emission and photosynthetic parameters in hybrid poplars exposed to free-air $\mathrm{CO}_{2}$ enrichment, Plant Cell Environ., 27, 403-412, 2004.

Claeys, M., Graham, B., Vas, G., Wang, W., Vermeylen, R., Pashynska, V., Cafmeyer, J., Guyon, P., Andreae, M. O., Artaxo, P., and Maenhaut, W.: Formation of secondary organic aerosols through photooxidation of isoprene, Science, 303, 1173-1176, 2004.

Clark, D. B., Mercado, L. M., Sitch, S., Jones, C. D., Gedney, N., Best, M. J., Pryor, M., Rooney, G. G., Essery, R. L. H., Blyth, E., Boucher, O., Harding, R. J., and Cox, P. M.: The Joint UK Land Environment Simulator (JULES), Model description - Part 2: Carbon fluxes and vegetation, Geosci. Model Dev. Discuss., 4, 641-688, doi:10.5194/gmdd-4-641-2011, 2011.

Collatz, G. J., Ball, J. T., Grivet, C., and Berry, J. A.: Physiological and environmental regulation of stomatal conductance, photosynthesis and transpiration: A model that includes a laminar boundary layer, Agr. Forest Meteorol., 54, 107-136, 1991.

Collatz, G. J., Ribas-Carbo, M., and Berry, J. A.: A coupled photosynthesis-stomatal conductance model for leaves of $\mathrm{C}_{4}$ plants, Aust. J. Plant Physiol., 19, 519-538, 1992.

Cox, P. M., Huntingford, C., and Harding, R. J.: A canopy conductance and photosynthesis model for use in a GCM land surface scheme, J. Hydrol., 213, 79-94, 1998.

Cox, P., M., Betts, R. A., Jones, C. D., Spall, S. A., and Totterdell, I.J.: Acceleration of global warming due to carboncyclefeedbacks in a coupled climate model, Nature, 408, 184187,2000

Cox, P. M.: Description of the "TRIFFID” Dynamic Global Vegetation Model. Technical note 24, Met Office Hadley Centre, Exeter, UK, 17 pp., 2001.

Delwiche, C. F. and Sharkey, T. D.: Rapid appearance of $13 \mathrm{C}$ in biogenic isoprene when $13 \mathrm{CO}_{2}$ is fed into intact leaves, Plant Cell Environ., 16, 587-591, 1993.

Essery, R. L. H., Best, M. J., Betts, R. A., Cox, P. M., and Taylor, C. M.: Explicit Representation of Subgrid Heterogeneity in a GCM Land Surface Scheme, J. Hydrometeorol., 4, 530-543, 2003.

Farquhar, G. D., Caemmerer, S., and Berry, J. A.: A biochemical model of photosynthetic $\mathrm{CO}_{2}$ assimilation in leaves of $\mathrm{C}_{3}$ species, Planta, 149, 78-90, 1980.

Fu, T., Jacob, D. J., Palmer, P. I., Chance, K., Wang, Y. X., Barletta, B., Blake, D. R., Stanton, J. C., and Pilling, M. J.: Space-based formaldehyde measurements as constraints on volatile organic compound emissions in east and south Asia and implications for ozone, J. Geophys. Res., 112, D06312, doi:10.1029/2006JD007853, 2007.

Goldstein, A. H., Goulden, M. L., Munger, J. W., Wofsy, S. C., and Geron, C. D.: Seasonal course of isoprene emissions from a midlatitude deciduous forest, J. Geophys. Res., 103(D23), 3104531056, 1998.

Guenther, A.: The contribution of reactive carbon emissions from vegetation to the carbon balance of terrestrial ecosystems, Chemosphere, 49, 837-844, 2002.

Guenther, A. B., Monson, R. K., and Fall, R.: Isoprene and monoterpene emission rate variability: observations with eucalyptus and emission rate algorithm development, J. Geophys. Res., 96, 10799-10808, 1991.

Guenther, A. B., Zimmerman, P. R., Harley, P. C., Monson, R. K., and Fall, R.: Isoprene and monoterpene emission rate variability - model evaluations and sensitivity analyses, J. Geophys. Res., 98(D7), 12609-12617, 1993.

Guenther, A., Hewitt, C. N., Erickson, D., Fall, R., Geron, C., Graedel, T., Harley, P., Klinger, L., Lerdau, M., Mckay, W. A., Pierce, T., Scholes, B., Steinbrecher, R., Tallamraju, R., Taylor, J., and Zimmerman, P.: A global model of natural volatile organic compound emissions, J. Geophys. Res., 100(D5), 8873$8892,1995$.

Guenther, A., Karl, T., Harley, P., Wiedinmyer, C., Palmer, P. I., and Geron, C.: Estimates of global terrestrial isoprene emissions using MEGAN (Model of Emissions of Gases and Aerosols from Nature), Atmos. Chem. Phys., 6, 3181-3210, doi:10.5194/acp-63181-2006, 2006.

Harley, P. C., Monson, R. K., and Lerdau, M. T.: Ecological and evolutionary aspects of isoprene emission from plants, Oecologia, 118, 109-123, 1999.

Hewitt, C. N. and Street, R. A.: A qualitative assessment of the emission of non methane hydrocarbon compounds from the biosphere to the atmosphere in the UK: present knowledge and uncertainties, Atmos. Environ., 26A(17), 3069-3077, 1992.

Hofzumahaus, A., Rohrer, F., Lu, K., Bohn, B., Brauers, T., Chang, C.-C., Fuchs, H., Holland, F., Kita, K., Kondo, Y., Li, X., Lou, S., Shao, M., Zeng, L., Wahner, A., and Zhang,Y.: Amplified trace gas removal in the troposphere, Science, 324, 1702-1704, 2009.

Holst, T., Arneth, A., Hayward, S., Ekberg, A., Mastepanov, M., Jackowicz-Korczynski, M., Friborg, T., Crill, P. M., and Bckstrand, K.: BVOC ecosystem flux measurements at a high latitude wetland site, Atmos. Chem. Phys., 10, 1617-1634, doi:10.5194/acp-10-1617-2010, 2010.

Johns, T. C., Durman, C. F., Banks, H. T., Roberts, M. J., McLaren, A. J., Ridley, J. K., Senior, C. A., Williams, K. D., Jones, A., Rickard, G. J., Cusack, S., Ingram, W. J., Crucifix, M., Sexton, D. M. H., Joshi, M. M., Dong, B.-W., Spencer, H., Hill, R. S. R., Gregory, J. M., Keen, A. B., Pardaens, A. K., Lowe, J. A., BodasSalcedo, A., Stark, S., and Searl, Y.: The new Hadley Centre climate model HadGEM1: Evaluation of coupled simulations, J. Climate, 19, 1327-1353, 2006.

Karl, T., Potosnak, M., Guenther, A., Clark, D., Walker, J., Herrick, J. D., and Geron, C.: Exchange processes of volatile organic compounds above a tropical rain forest: Implications for modeling tropospheric chemistry above dense vegetation, J. Geophys Res.-Atmos., 109(D18), D18306, doi:10.1029/2004JD004738, 
2004.

Karl, T., Guenther, A., Yokelson, R.J., Greenberg, J., Potosnak, M., Blake, D. R., and Artaxo, P.: The tropical forest and fire emissions experiment: emission, chemistry, and transport of biogenic volatile organic compounds in the lower atmosphere over Amazonia, J. Geophys. Res., 112, D18302, doi:10.1029/2007JD008539, 2007.

Kesselmeier, J. and Staudt M.: Biogenic volatile organic compounds (VOC): An overview on emission, physiology and ecology, J. Atmos. Chem., 33, 23-88, 1999.

Loveland, T. R., Reed, B. C., Brown, J. F., Ohlen, D. O., Zhu, Z., Yang, L., and Merchant, J. W.: Development of a global land cover characteristics database and IGBP DISCover from $1 \mathrm{~km}$ AVHRR data, Int. J. Remote Sens., 21(6-7), 1303-1330, 2000.

Martin, M. J., Stirling, C. M., Humphries, S. W., and Long, S. P.: A process-based model to predict the effects of climatic change on leaf isoprene emission rates, Ecol. Model., 131, 161-174, 2000.

Mercado, L. M., Huntingford, C., Gash, J. H. C., Cox, P. M., and Jogireddy, V.: Improving the representation of radiation interception and photosynthesis for climate model applications, TellusB, 59, 553-565, 2007.

Monson, R. K. and Fall, R.: Isoprene emission from aspen leaves, PlantPhysiol., 90, 267-274, 1989.

Monson, R. K., Jaeger, C. H., Adams, W. W., Driggers, E. M., Silver, G. M., and Fall, R.: Relationships among isoprene emission rate, photosynthesis, and isoprene synthase activity as influenced by temperature, Plant Physiol., 98, 1175-1180, 1992.

Monson, R. K., Trahan, N., Rosenstiel, T. N., Veres, P., Moore, D., Wilkinson, M., Norby, R.J., Volder, A., Tjoelker, M. G., Briske, D. D., Karnosky, D. F., and Fall, R.: Isoprene emission from terrestrial ecosystems in response to global change: minding the gap between models and observations, Philos. T. Roy. Soc. A., 365, 1677-1695, 2007.

Müller, J.-F., Stavrakou, T., Wallens, S., De Smedt, I., Van Roozendael, M., Potosnak, M. J., Rinne, J., Munger, B., Goldstein, A., and Guenther, A. B.: Global isoprene emissions estimated using MEGAN, ECMWF analyses and a detailed canopy environment model, Atmos. Chem. Phys., 8, 1329-1341, doi:10.5194/acp-81329-2008, 2008.

Niinemets, Ü., Tenhunen, J. D., Harley, P. C., and Steinbrecher, R.: A model of isoprene emission based on energetic requirements for isoprene synthesis and leaf photosynthetic properties for Liquidambar and Quercus, Plant Cell Environ., 22, 13191335, 1999.

Niinemets, Ü., Arneth, A., Kuhn, U., Monson, R. K., Peñuelas, J., and Staudt, M.: The emission factor of volatile isoprenoids: stress, acclimation, and developmental responses, Biogeosciences, 7, 2203-2223, doi:10.5194/bg-7-2203-2010, 2010a.

Niinemets, Ü., Monson, R. K., Arneth, A., Ciccioli, P., Kesselmeier, J., Kuhn, U., Noe, S. M., Peñuelas, J., and Staudt, M.: The leaflevel emission factor of volatile isoprenoids: caveats, model algorithms, response shapes and scaling, Biogeosciences, 7, 18091832, doi:10.5194/bg-7-1809-2010, 2010b.

Pacifico, F., Harrison, S. P., Jones, C. D., and Sitch, S.: Isoprene emissions and climate, Atmos. Environ., 43(39), 6121-6135, 2009.

Palmer, P. I., Jacob, D. J., Fiore, A. M., Martin, R. V., Chance, K., and Kurosu, T. P.: Mapping isoprene emissions over North
America using formaldehyde column observations from space, J. Geophys. Res., 108(D6), 4180, doi:10.1029/2002JD002153, 2003.

Palmer, P. I., Abbot, D. S., Fu, T.-M., Jacob, D. J., Chance, K., Kurosu, T. P., Guenther, A., Wiedinmyer, C., Stanton, J. C., Pilling, M.J., Pressley, S. N., Lamb, B., and Sumner, A. L.: Quantifying the seasonal and interannual variability of North American isoprene emissions using satellite observations of the formaldehyde column, J. Geophys. Res., 111, D12315, doi:10.1029/2005JD006689, 2006.

Pegoraro, E., Rey, A., Bobich, E. G., Barron-Gafford, G., Grieve, K. A., Malhi, Y., and Murthy, R.: Effect of elevated $\mathrm{CO}_{2}$ concentration and vapour pressure deficit on isoprene emission from leaves of Populus deltoides during drought, Funct. Plant Biol., 31, 1137-1147, 2004.

Pressley, S., Lamb, B., Westberg, H., Flaherty, J., Chen, J., and Vogel, C.: Long-term isoprene flux measurements above a northern hardwood forest, J. Geophys. Res., 110, D07301, doi:10.1029/2004JD005523, 2005.

Pressley, S., Lamb, B., Westberg, H., and Vogel, C.: Relationships among canopy scale energy fluxes and isoprene flux derived from long-term, seasonal eddy covariance measurements over a hardwood forest, Agr. Forest Meteorol., 136, 188-202, 2006.

Rosenstiel, T. N., Ebbets, A. L., Khatri, W. C., Fall, R., and Monson, R. K.: Induction of Poplar leaf nitrate reductase: A test of extrachloroplastic control of Isoprene emission rate, Plant Biol., 6, 12-21, 2004.

Sanadze, G. A.: Biogenic isoprene (a review), Russ. J. Plant Physl., 51(6), 729-741, 2004.

Sanderson, M. G., Jones, C. D., Collins, W. J., Johnson, C. E., and Derwent, R. G.: Effect of climate change on isoprene emissions and surface ozone levels, Geophys. Res. Lett., 30(18), 1936, doi:10.1029/2003GL017642, 2003.

Sellers, P. J., Berry, J. A., Collatz, G. J., Field, C. B., and Hall, F. G.: Canopy reflectance, photosynthesis, and transpiration III. A reanalysis using improved leaf models and a new canopy integration scheme, Remote Sens. Environ., 42, 187-216, 1992.

Sharkey, T. D.: Photosynthesis in intact leaves of $\mathrm{C}_{3}$ plants: physics, physiology and rate limitations, Bot. Rev., 51(1), 53$105,1985$.

Sharkey, T. D. and Loreto, F.: Water stress, temperature, and light effects on the capacity for isoprene emission and photosynthesis of kudzu leaves, Oecologia, 95, 328-333, 1993.

Shim, C., Wang, Y., Choi, Y., Palmer, P. I., Abbot, D., and Chance, K.: Constraining global isoprene emissions with Global Ozone Monitoring Experiment (GOME) formaldehyde column measurements, J. Geophys. Res., 110, D24301, doi:10.1029/2004JD005629, 2005.

Schurgers, G., Hickler, T., Miller, P. A., and Arneth, A.: European emissions of isoprene and monoterpenes from the Last Glacial Maximum to present, Biogeosciences, 6, 2779-2797, doi:10.5194/bg-6-2779-2009, 2009.

Sitch, S., Smith, B., Prentice, I. C., Arneth, A., Bondeau, A., Cramer, W., Kaplan, J. O., Levis, S., Lucht, W., Sykes, M. T., Thonicke, K., and Venevsky, S.: Evaluation of ecosystem dynamics, plant geography and terrestrial carbon cycling in the LPJ dynamic global vegetation model, Glob. Change Biol., 9(2), 161-185, 2003.

Smith, B., Prentice, I. C., and Sykes, M. T.: Representation of 
vegetation dynamics in the modelling of terrestrial ecosystems: comparing two contrasting approaches within European climate space, Global Ecol. Biogeogr., 10, 621-637, 2001.

Stroud, C., Makar, P., Karl, T., Guenther, A., Geron, C., Turnipseed, A., Nemitz, E., Baker, B., Potosnak, M., and Fuentes, J.: Role of Canopy-Scale Photochemistry in Modifying BiogenicAtmosphere Exchange of Reactive Terpene Species: Results from the CELTIC Field Study, J. Geophys. Res., 110, D17303, doi:10.1029/2005JD005775, 2005.

Telford, P. J., Lathière, J., Abraham, N. L., Archibald, A. T., Braesicke, P., Johnson, C. E., Morgenstern, O., O’Connor, F. M., Pike, R. C., Wild, O., Young, P. J., Beerling, D. J., Hewitt, C. N., and Pyle, J.: Effects of climate-induced changes in isoprene emissions after the eruption of Mount Pinatubo, Atmos. Chem. Phys., 10, 7117-7125, doi:10.5194/acp-10-7117-2010, 2010.

Valdes, P. J., Beerling, D. J., and Johnson, C. E.: The ice age methane budget, Geophys. Res. Lett., 32, L02704, doi:10.1029/2004GL021004, 2005.

Weedon, G. P., Gomes, S., Viterbo, P., Osterle, H., Adam, J. C., Bellouin, N., Boucher, O., and Best, M.: The WATCH forcing data 1958-2001: a meteorological forcing dataset for land surface and hydrological models, WATCH technical report 22, available at: http://www.eu-watch.org, 2010.
Wiberley, A. E., Linskey, A. R., Falbel, T. G., and Sharkey, T. D.: Development of the capacity for isoprene emission in kudzu, Plant Cell Environ., 28(7), 898-905, 2005.

Wiedinmyer, C., Guenther, A., Harley, P., Hewitt, C. N., Geron, C., Artaxo, P., Steinbrecher, R., and Rasmussen, R.: Global organic emissions from vegetation, in: Emissions of Atmospheric Trace Compounds, edited by: Granier, C., Artaxo, P., and Reeves, C. E, Kluwer Publishing Co, Dordrecht, The Netherlands, 115-170, 2004.

Wolter, K. and Timlin, M.: Monitoring ENSO in COADS with a seasonally adjusted principal component index, in: Proc. of the 17th Climate Diagnostics Workshop, Norman, OK, NOAA/N MC/CAC, NSSL, Oklahoma Clim. Survey, CIMMS and the School of Meteor., Univ. of Oklahoma, 52-57, 1993.

Wolter, K. and Timlin, M. S.: Measuring the strength of ENSO events - how does 1997/98 rank?, Weather, 53, 315-324, 1998.

Young, P. J., Arneth, A., Schurgers, G., Zeng, G., and Pyle, J. A.: The $\mathrm{CO}_{2}$ inhibition of terrestrial isoprene emission significantly affects future ozone projections, Atmos. Chem. Phys., 9, 27932803, doi:10.5194/acp-9-2793-2009, 2009.

Zimmer, W., Steinbrecher, R., Körner, C., and Schnitzler, J.-P.: The process-based SIM-BIM model: towards more realistic prediction of isoprene emissions from adult Quercus petrea forest trees, Atmos. Environ., 37(12), 1665-1671, 2003. 